\title{
Glucose metabolism and the somatotropic axis in dairy cows after abomasal infusion of essential fatty acids together with conjugated linoleic acid during late gestation and early lactation
}

\author{
L. Vogel, ${ }^{1}$ M. Gnott, ${ }^{1}$ C. Kröger-Koch, ${ }^{1}$ S. Görs, ${ }^{1}$ J. M. Weitzel, ${ }^{2}$ E. Kanitz, ${ }^{3}$ A. Hoeflich, ${ }^{4} \oplus$ A. Tuchscherer, ${ }^{5}$ \\ A. Tröscher, ${ }^{6}$ (D) J. J. Gross, ${ }^{7}$ (D) R. M. Bruckmaier, ${ }^{7}$ (D) A. Starke, ${ }^{8}$ L. Bachmann, ${ }^{1}$ (D) and H. M. Hammon ${ }^{1 *}$ (D) \\ ${ }^{1}$ Institute of Nutritional Physiology "Oskar Kellner," Leibniz Institute for Farm Animal Biology (FBN), 18196 Dummerstorf, Germany \\ ${ }^{2}$ Institute of Reproductive Biology, Leibniz Institute for Farm Animal Biology (FBN), 18196 Dummerstorf, Germany \\ ${ }^{3}$ Institute of Behavioral Physiology, Leibniz Institute for Farm Animal Biology (FBN), 18196 Dummerstorf, Germany \\ ${ }^{4}$ Institute of Genome Biology, Leibniz Institute for Farm Animal Biology (FBN), 18196 Dummerstorf, Germany \\ ${ }^{5}$ Institute of Genetics and Biometry, Leibniz Institute for Farm Animal Biology (FBN), 18196 Dummerstorf, Germany \\ ${ }^{6}$ BASF SE, 68619 Lampertheim, Germany \\ ${ }^{7}$ Veterinary Physiology, Vetsuisse Faculty, University of Bern, 3012 Bern, Switzerland \\ ${ }^{8}$ Clinic for Ruminants and Swine, Faculty of Veterinary Medicine, University of Leipzig, 04103 Leipzig, Germany
}

\section{ABSTRACT}

Sufficient glucose availability is crucial for exploiting the genetic potential of milk production during early lactation, and endocrine changes are mainly related to repartitioning of nutrient supplies toward the mammary gland. Long-chain fatty acids, such as essential fatty acids (EFA) and conjugated linoleic acid (CLA), have the potential to improve negative energy balance and modify endocrine changes. In the present study, the hypothesis that combined CLA and EFA treatment supports glucose metabolism around the time of calving and stimulates insulin action and the somatotropic axis in cows in an additive manner was tested. Rumencannulated German Holstein cows $(\mathrm{n}=40)$ were investigated from wk 9 antepartum (AP) until wk 9 postpartum (PP). The cows were abomasally supplemented with coconut oil (CTRL, $76 \mathrm{~g} / \mathrm{d}$ ); $78 \mathrm{~g} / \mathrm{d}$ of linseed and $4 \mathrm{~g} / \mathrm{d}$ of safflower oil (EFA); Lutalin (CLA, isomers cis-9,trans-11 and trans-10,cis-12 CLA, each $10 \mathrm{~g} / \mathrm{d}$ ); or the combination of EFA+CLA. Blood samples were collected several times $\mathrm{AP}$ and $\mathrm{PP}$ to determine the concentrations of plasma metabolites and hormones related to glucose metabolism and the somatotropic axis. Liver tissue samples were collected several days AP and $\mathrm{PP}$ to measure glycogen concentration and the mRNA abundance of genes related to gluconeogenesis and the somatotropic axis. On d $28 \mathrm{AP}$ and $21 \mathrm{PP}$, endogenous glucose production (eGP) and glucose oxidation (GOx)

Received July 20, 2020.

Accepted October 7, 2020.

*Corresponding author: hammon@fbn-dummerstorf.de were measured via tracer technique. The concentration of plasma glucose was higher in CLA than in nonCLA-treated cows, and the plasma $\beta$-hydroxybutyrate concentration was higher in EFA than in non-EFA cows on d $21 \mathrm{PP}$. The eGP increased from AP to PP with elevated eGP in EFA and decreased eGP in CLA-treated cows; GOx was lower in CLA than in CTRL on d 21 PP. The plasma insulin concentration decreased after calving in all groups and was higher in CLA than in non-CLA cows at several time points. Plasma glucagon and cortisol concentrations on d $21 \mathrm{PP}$ were lower in CLA than non-CLA groups. The glucagon/insulin and glucose/insulin ratios were higher in CTRL than in CLA group during the transition period. Plasma IGF-I concentration was lower in EFA than non-EFA cows on d $42 \mathrm{AP}$ and was higher during the dry period and early lactation in CLA than in non-CLA cows. The IGF binding protein (IGFBP)-3/-2 ratio in blood plasma was higher in CLA than in non-CLA cows. Hepatic glycogen concentration on d $28 \mathrm{PP}$ was higher, but the mRNA abundance of $P C$ and IGFBP2 was lower in CLA than non-CLA cows on d 1 PP. The EFA treatment decreased the mRNA abundance of IGFBP3 AP and PCK1, PCK2, G6PC, PCCA, HMGCS2, IGFBP2, and $I N S R$ at several time points PP. Results indicated elevated concentrations of plasma glucose and insulin along with the stimulation of the somatotropic axis in cows treated with CLA, whereas EFA treatment stimulated eGP but not mRNA abundance related to eGP PP. The systemic effects of the combined EFA+CLA treatment were very similar to those of CLA treatment, but the effects on hepatic gene expression partially corresponded to those of EFA treatment.

Key words: $\alpha$-linolenic acid, conjugated linoleic acid, glucose metabolism, somatotropic axis 


\section{INTRODUCTION}

The time period from late gestation to early lactation involves substantial metabolic and endocrine changes in dairy cows that are related to the repartitioning of the nutrient supply for milk production (Bauman, 2000; Drackley et al., 2001; Gross and Bruckmaier, 2019). Providing sufficient glucose is an important prerequisite for exploiting the genetic potential for milk synthesis (Bauman, 2000; Drackley et al., 2001). Glucose is needed for the synthesis of lactose, which is the major osmoregulator of mammary water uptake, and consequently, milk volume (Linzell, 1972), as well as milk fat synthesis (Grummer and Carroll, 1991). Postcalving, glucose metabolism adapts by increasing endogenous glucose production (eGP) and decreasing peripheral glucose utilization in tissues other than the mammary gland (Drackley et al., 2001; Aschenbach et al., 2010; Hammon et al., 2016). There are marked changes in the hepatic gene expression of enzymes related to gluconeogenesis that reflect the increased glucose demands and changes in substrate availability associated with the onset of lactation (Aschenbach et al., 2010; Donkin, 2016; Hammon et al., 2016). The endocrine regulation of nutrition partitioning during the transition period and the glucose supply for milk synthesis involve insulin action and the somatotropic axis (Bauman, 2000; Drackley et al., 2001; Lucy, 2004). Insulin sensitivity is decreased, and the growth hormone (GH)-IGF-I axis is uncoupled during early lactation to favor the mobilization of body energy reserves and the provision of substrates such as glucose for milk production (Etherton and Bauman, 1998; Drackley et al., 2001; De Koster and Opsomer, 2013).

The feeding of various fatty acids (FA) can relieve the energy load in dairy cows during early lactation. The supplementation of trans-10,cis-12 CLA causes milk fat depression, which has the potential to improve the energy balance in early lactation (Baumgard et al., 2000; Odens et al., 2007). The CLA supplementation leads to nutrient repartitioning toward increased lactose release and decreased eGP, resulting in a glucose-sparing effect during early lactation (Hötger et al., 2013). Interestingly, trans-10, cis-12 CLA causes an insulin-resistant state in rodent and human (Riserus et al., 2002; Halade et al., 2010; Bezan et al., 2018). The effects of CLA treatment on endocrine changes associated with nutrient partitioning and the gene expression of gluconeogenic enzymes in the liver of dairy cows are less clear. In addition, common rations for dairy cows contain high levels of corn silage in the TMR, providing forage with a high energy density but low amounts of fat and essential fatty acids (EFA) with a high n-6/n-3 FA ratio (Chilliard et al., 2001; Barkema et al., 2015).
Interestingly, n-3 FA supplementation improves insulin sensitivity in mice and in cattle (Pires and Grummer, 2008; Fortin et al., 2010; Fan et al., 2020). The gene expression of enzymes related to gluconeogenesis seems to be under the control of long-chain FA (White et al., 2011), and n-3 FA stimulate whole-body glycogen storage (Clarke, 2001).

The aim of the present study was to investigate the effect of combined CLA and EFA supplementation on glucose metabolism and the regulation of nutrition partitioning by the somatotropic axis in dairy cows during late gestation and early lactation. Previous findings within this project confirmed the improvement of the energy balance around the time of calving in cows associated with combined CLA and EFA supplementation (Vogel et al., 2020). Therefore, the tested hypothesis was that CLA and EFA treatments during the transition from late pregnancy to early lactation affect glucose metabolism and stimulate insulin action and the somatotropic axis, respectively, and that the combined EFA and CLA treatment may support these endocrine changes in an additive manner.

\section{MATERIALS AND METHODS}

\section{Animals, Husbandry, Fatty Acid Supplementation, and Feeding}

All experimental procedures were carried out in compliance with the German Animal Welfare Act and were approved by the animal ethics committee of the state of Mecklenburg-Western Pomerania, Germany (Landesamt für Landwirtschaft, Lebensmittelsicherheit und Fischerei Mecklenburg-Vorpommern; LALLF M-V/TSD/7221.3-1-038/15).

A detailed description of the study design, feeding management, and diet composition was published recently (Vogel et al., 2020). Briefly, from December 2015 to September 2017, German Holstein cows $(\mathrm{n}=40)$ were investigated in 5 blocks consisting of 8 cows $(2$ cows per group; 2 cows were removed from the evaluation because of premature calving). The German Holstein cows were purchased from a local farm (Agrarprodukte Dedelow GmbH, Prenzlau, Germany) in approximately wk 18 of gestation during their second lactation and were kept in a freestall barn at the Leibniz Institute for Farm Animal Biology (FBN), Dummerstorf, Germany. Before the beginning of the trial, the cows were surgically fitted with rumen cannulas (\#2C or \#1C 4 in; Bar Diamond Inc., Parma, ID) as described previously (Haubold et al., 2020; Vogel et al., 2020). The cows were assigned to 4 supplementation groups exhibiting comparable projected milk production, BW, and calving interval. The cows were supplemented daily from 63 
d antepartum (AP) until slaughter on d 63 postpartum (PP) with 1 of the 4 following treatments: $76 \mathrm{~g} / \mathrm{d}$ of coconut oil (CTRL, n = 9; Bio-Kokosöl \#665, Kräuterhaus Sanct Bernhard KG, Bad Ditzenbach, Germany); $78 \mathrm{~g} / \mathrm{d}$ of linseed plus $4 \mathrm{~g} / \mathrm{d}$ of safflower oil (EFA, $\mathrm{n}=9$; linseed oil, DERBY Leinöl \#4026921003087, DERBY Spezialfutter GmbH, Münster, Germany; safflower oil, GEFRO Distelöl, GEFRO Reformversand Frommlet KG, Memmingen, Germany; linseed/ safflower oil ratio $=19.5: 1 ; \mathrm{n}-6 / \mathrm{n}-3 \mathrm{FA}$ ratio $=1: 3$ ); $38 \mathrm{~g} / \mathrm{d}$ of Lutalin (CLA, $\mathrm{n}=10 ; 27.2 \%$ cis-9,trans-11 and $27.0 \%$ trans-10, cis-12 CLA in Lutalin, BASF SE, Ludwigshafen, Germany); or $120 \mathrm{~g} / \mathrm{d}$ of the mixture of linseed and safflower oil plus Lutalin in the same mentioned quantities (EFA+CLA, $\mathrm{n}=10)$. During the dry period, each dose was halved. The amounts and FA composition of the daily infused supplements, which are shown in Supplemental Tables S1 and S2 (https:/ /doi.org/10.22000/358), were recently evaluated in a companion dose-response study in mid-lactating dairy cows (Haubold et al., 2020). The treatments were abomasally infused twice a day (2 equal portions) at 0700 and $1630 \mathrm{~h}$ via infusion lines using 60-mL catheter tip syringes. All supplements were liquefied by heating to $38^{\circ} \mathrm{C}$ to allow infusion. The placement of the abomasal infusion line was confirmed weekly by palpation. Observations and sampling were performed from wk 10 before calving until wk 9 during the third lactation. At $40 \pm 6 \mathrm{~d}$ AP (mean $\pm \mathrm{SD}$ ), the cows were dried off, and from $10 \mathrm{~d}$ before until $1 \mathrm{~d}$ after parturition, the cows were housed in straw-bedded calving boxes. The cows were slaughtered on d $63 \pm 3 \mathrm{PP}$ (mean $\pm \mathrm{SD}$ ).

The cows were fed a corn silage-based TMR during late and early lactation (wk 22-6 AP and wk 1-9 PP) and during the dry period (wk 6-1 AP). We recently published the details of the feed sampling procedure and analyses in a companion paper (Vogel et al., 2020). The ingredients and chemical composition of the diets are shown Table 1. The major FA concentrations in the diets are shown in Supplemental Table S3 (https://doi .org/10.22000/358). The diets were provided ad libitum beginning at $0600 \mathrm{~h}$, and the cows had free access to water as well as trace-mineralized salt blocks. After calving, a calcium bolus (RUMINCa ${ }^{\mathrm{DL}}$, Wirtschaftsgenossenschaft Deutscher Tierärzte eG; Garbsen, Germany) and $300 \mathrm{~mL} / \mathrm{d}$ 1,2-propanediol (Propylenglykol USP; Dr. Pieper Technologie- und Produktentwicklung GmbH, Wuthenow, Germany) were administered intraruminally on 3 consecutive days. Individual daily feed intake was recorded as the disappearance of feed from troughs connected to an electronic scale, to which access was controlled by individual transponders (Institute for Agricultural Engineering and Animal Husbandry ILT, Bavarian State Research Center for
Table 1. Ingredients and chemical composition of the diets

\begin{tabular}{|c|c|c|}
\hline \multirow[b]{2}{*}{ Item, $\mathrm{g} / \mathrm{kg}$ of $\mathrm{DM}$} & \multicolumn{2}{|c|}{ Diet } \\
\hline & Lactation & Dry period $^{1}$ \\
\hline \multicolumn{3}{|l|}{ Ingredient } \\
\hline Corn silage & 457 & 421 \\
\hline Straw & 97 & 223 \\
\hline Compound feed DEFA ${ }^{2}$ (granulated) & 446 & - \\
\hline Dried sugar beet pulp & - & 163 \\
\hline Extracted soybean meal & - & 99 \\
\hline Rye grain & - & 75 \\
\hline Minerals and vitamins ${ }^{3}$ & - & 10 \\
\hline Urea $^{4}$ & - & 9 \\
\hline \multicolumn{3}{|l|}{ Chemical composition $^{5}$} \\
\hline $\mathrm{NE}_{\mathrm{L}}, \mathrm{MJ} / \mathrm{kg}$ of $\mathrm{DM}$ & 7.1 & 6.5 \\
\hline Crude fat & 23 & 21 \\
\hline Crude fiber & 173 & 219 \\
\hline $\mathrm{CP}$ & 146 & 141 \\
\hline Utilizable protein & 143 & 141 \\
\hline $\mathrm{NFC}$ & 432 & 379 \\
\hline NDF & 346 & 423 \\
\hline $\mathrm{ADF}$ & 197 & 249 \\
\hline RNB & 0.5 & 0.0 \\
\hline
\end{tabular}

${ }^{1}$ The dry period diet was fed from wk 6 to 1 before calving. The actual dry period started $40 \pm 6 \mathrm{~d}$ before birth.

${ }^{2}$ Ceravis AG, Malchin, Germany. Ingredients: $46.5 \%$ dried sugar beet pulp, $25.3 \%$ extracted soybean meal, $23.8 \%$ grain of rye, $1.4 \%$ urea, $1.1 \%$ premix cow, $1.00 \%$ calcium, $0.37 \%$ phosphorus, $0.42 \%$ sodium, vitamins $\mathrm{A}, \mathrm{D}_{3}$, E, copper, ferric, zinc, manganese, cobalt, iodine, selenium. Chemical composition: $44.4 \% \mathrm{NFC}, 24.1 \% \mathrm{CP}, 21.6 \% \mathrm{NDF}$, $12.4 \% \mathrm{ADF}, 9.3 \%$ crude fiber, $8.2 \%$ crude ash, $1.8 \%$ crude fat, and 7.9 $\mathrm{MJ}$ of $\mathrm{NE}_{\mathrm{L}} / \mathrm{kg}$ of DM.

${ }^{3}$ Concentrations of minerals and vitamins (KULMIN MFV Plus, Bergophor Futtermittelfabrik Dr. Berger GmbH \& Co., KG, Kulmbach, Germany): $8.5 \%$ magnesium, $7.5 \%$ phosphorus, $6.5 \%$ sodium, $3.5 \%$ $\mathrm{HCl}$-insoluble ash, $1.5 \%$ calcium; vitamins and trace minerals per $\mathrm{kg}$ : $1,000,000 \mathrm{IU}$ of vitamin $\mathrm{A}, 200,000 \mathrm{IU}$ of vitamin $\mathrm{D}_{3}, 10,000 \mathrm{mg}$ of vitamin $\mathrm{E}, 180 \mathrm{mg}$ of vitamin $\mathrm{B}_{1}, 90 \mathrm{mg}$ of vitamin $\mathrm{B}_{2}, 90 \mathrm{mg}$ of vitamin $\mathrm{B}_{6}, 200 \mathrm{mg}$ of vitamin $\mathrm{B}_{5}, 2,500 \mathrm{mg}$ of vitamin $\mathrm{B}_{3}, 675 \mathrm{mg}$ of vitamin $B_{12}, 12 \mathrm{mg}$ of vitamin $B_{9}, 100 \mathrm{mg}$ of vitamin $\mathrm{H}, 2,500 \mathrm{mg}$ of zinc, $3,500 \mathrm{mg}$ of manganese, $500 \mathrm{mg}$ of copper, $20 \mathrm{mg}$ of cobalt, $75 \mathrm{mg}$ of iodine, $30 \mathrm{mg}$ of selenium as sodium selenite, and $15 \mathrm{mg}$ of Se from Saccharomyces cerevisiae.

${ }^{4}$ Piarumin (SKW Stickstoffwerke Piesteritz GmbH, Lutherstadt Wittenberg, Germany): $99 \%$ urea, $46.5 \%$ total nitrogen.

${ }^{5} \mathrm{NE}_{\mathrm{L}}$, utilizable protein, and ruminal nitrogen balance $(\mathrm{RNB})=$ German Society of Nutrition Physiology $(2001,2008,2009)$ and Deutsche Landwirtschaftliche Gesellschaft (DLG, 2013).

Agriculture LfL, Freising, Germany). The cows were milked twice daily at 0630 and $1800 \mathrm{~h}$, and the milk yield was recorded electronically.

\section{Blood and Liver Tissue Sampling and Analyses}

A detailed description of the sampling procedures was published in a companion paper (Vogel et al., 2020). Blood samples were collected $63,42,35,28,21$, and $10 \mathrm{~d}$ before expected calving, $1 \mathrm{~d}$ after calving, and then once weekly up to d 56 immediately after morning milking and before feeding via jugular vein puncture using a Vacuette system (Greiner Bio-One In- 
ternational GmbH, Kremsmünster, Austria) containing either $\mathrm{K}_{3}$ EDTA $(1.8 \mathrm{~g} / \mathrm{L})$ for the analysis of hormones of the somatotropic axis or sodium fluoride $(2-4 \mathrm{~g} / \mathrm{L})$ in combination with potassium oxalate $(1-3 \mathrm{~g} / \mathrm{L})$ as an anticoagulant for the measurement of plasma metabolites. Immediately after collection, the samples were cooled on crushed ice and centrifuged at 1,500 $\times$ $g\left(4^{\circ} \mathrm{C}, 20 \mathrm{~min}\right)$. The supernatant was harvested and stored at $-20^{\circ} \mathrm{C}$ until analysis.

Plasma metabolites were analyzed using an automatic spectrophotometer (ABX Pentra 400; HORIBA ABX SAS, Montpellier, France) and specific kits for glucose (\#A11A01667, hexokinase-glucose-6-phosphate dehydrogenase method; HORIBA ABX SAS, Montpellier, France) and BHB (\#RB 1008, 3-hydroxybutyrate dehydrogenase method; Randox Laboratories Ltd., Crumlin, UK). The interassay variations were $<4 \%$ for glucose and $<5 \%$ for BHB when testing for control plasma with low, medium, and high concentrations. The concentrations of plasma insulin (\#RIA-1257) and glucagon (\#RIA-1258) were determined via RIA using kits from DRG Instruments GmbH (Marburg, Germany) adapted for cattle (Hammon et al., 2009). The intra- and interassay coefficients of variation were 3.7 and $5.5 \%$ for insulin and 4.6 and $\mathbf{1 3 . 4 \%}$ for glucagon. Plasma cortisol concentrations were analyzed using a commercially available ELISA kit (\#EIA1887; DRG Instruments GmbH, Marburg, Germany) according to the manufacturer's instructions. The assay was validated for use with bovine plasma (Weber et al., 2013b). The test sensitivity was $3.5 \mathrm{ng} / \mathrm{mL}$, and the intra- and interassay coefficients of variation were 4.7 and $12.7 \%$, respectively. Plasma growth hormone (GH) and IGFI were measured by radioimmunoassay as described previously (Vicari et al., 2008). Intra- and interassay coefficients of variation for GH and IGF-I RIA were below 10 and 15\%, respectively. Concentrations of plasma IGFBP were analyzed via quantitative Western ligand blot analysis as previously described using plasma samples containing $\mathrm{K}_{3}$ EDTA (Wirthgen et al., 2016). The intra- and interassay coefficients of variation were $<15 \%$ and $<20.0 \%$ for all IGFBP, respectively.

Liver biopsy samples were obtained after morning milking by needle biopsy under local anesthesia on $\mathrm{d}$ 63 and 21 before calving and d 1 and $28 \mathrm{PP}$ by using a tailor-made biopsy needle (length $400 \mathrm{~mm}$; outer diameter of $6 \mathrm{~mm}$; Weber et al., 2013b). Additional samples were collected during slaughter on d $63 \mathrm{PP}$. Liver samples were immediately frozen in liquid nitrogen and stored at $-80^{\circ} \mathrm{C}$ until analysis. Liver tissue was ground in liquid nitrogen, and glycogen content was determined using a commercial photometric kit based on the amyloglucosidase-catalyzed release of glucose
(ENZYTEC Starch \#E1268, R-Biopharm AG, Darmstadt, Germany).

For gene expression analysis, liver tissue was homogenized using a FastPrep 120 centrifuge (Thermo Electron Corporation, Waltham, MA), and total RNA was isolated from the liver samples with TRIzol Reagent (Life Technologies, Darmstadt, Germany), cleaned with an RNeasy Mini Kit (Qiagen GmbH, Hilden, Germany), and transcribed into cDNA as described by Hammon et al. (2009). The integrity, quantity, and quality of total RNA were confirmed according to Haubold et al. (2020). The mean RNA integrity number for liver tissue was $6 \pm 1$. The quantity and purity of the total RNA were assessed on the basis of optical density measurements, and the A260:280 ratio ranged from 1.8 to 2.0. The relative mRNA abundance of genes related to glucose metabolism and the somatotropic axis was quantified as described by Saremi et al. (2012). The primer sequences and PCR conditions used for the reference genes low-density lipoprotein 10 (LRP10) and RNA polymerase II (POLR2A) and the target genes related to glucose metabolism and the somatotropic axis are reported in Supplemental Table S4 (https://doi.org/10 .22000/358). The selected targets were genes encoding enzymes involved in glucose metabolism, such as pyruvate carboxylase $(P C)$, cytosolic and mitochondrial phosphoenolpyruvate carboxykinase (cytosolic PCK1; mitochondrial PCK2), glucose-6-phosphatase (G6PC), and propionyl-CoA-carboxylase $\alpha(P C C A)$, or ketogenesis, such as 3-hydroxy-3-methyl-glutaryl-CoA synthase 2 (HMGCS2). Additionally, genes encoding hormones or receptors involved in the somatotropic axis, such as GH receptor 1A (GHR1A), IGF-I (IGF1), insulin receptor (INSR), and IGFBP-2 and -3 (IGFBP2; IGFBP3), were investigated. The primer products were verified by sequencing with the BigDye Terminator v1.1 Cycle Sequencing Kit and an ABI 3130 Genetic Analyzer (Thermo Fisher Scientific Inc., Waltham, MA).

The mRNA expression relative to reference genes was performed by real-time reverse-transcription PCR with the use of a LightCycler 96 (Roche Diagnostics GmbH, Mannheim, Germany); SYBR Green I was used as the fluorescent dye. Duplicate measurements were performed for all samples, and each block included 2 negative controls (no cDNA and no RT) and 2 interrun calibrators. Melting curve analysis and agarose gel electrophoreses were used to confirm the specificity of the PCR products. The quantification cycle values and amplification efficiencies obtained with LinRegPCR version 2017.0 (Ruijter et al., 2013) were imported into qBASE+ version 3.1 (Biogazelle, Gent, Belgium) for all subsequent calculations and quality controls. The geometric mean of the reference gene abundance was 
applied for normalization. The data are presented as the ratio of the copy number of the gene of interest to the geometric mean reference gene abundance.

\section{Tracer Studies}

On d 28 before expected calving and d 21 PP, eGP and glucose oxidation $(\mathbf{G O x})$ were determined after feed withdrawal for $12 \mathrm{~h}$ via the primed continuous intravenous infusion of $\left[\mathrm{U}_{-}{ }^{13} \mathrm{C}\right]$-glucose $\left[99\right.$ atom $\%{ }^{13} \mathrm{C}$, Euriso-Top SAS, Staint-Aubin Cedex, France; prime: $5.38 \mu \mathrm{mol} / \mathrm{kg}$ of $\mathrm{BW}$; infusion: $7.53 \mu \mathrm{mol} /(\mathrm{kg}$ of $\mathrm{BW}$ $\times \mathrm{h}$ ); dissolved in $0.9 \%$ saline] for $4 \mathrm{~h}$ (Hammon et al., 2008; Hötger et al., 2013; Weber et al., 2016). Cows were fitted with 2 jugular catheters (Cavafix Certo with Splittocan, B. Braun Vet Care GmbH, Tuttlingen, Germany) for tracer infusion and blood sampling. Blood samples were collected 30 and 20 min before tracer infusion and at 60,120, 150, 180, 210, and 240 min after the initiation of infusion in tubes containing Li-heparin (14-15 IU/mL; S-Monovette, Sarstedt, Nürnberg, Germany). The enrichment of $\left[\mathrm{U}-{ }^{13} \mathrm{C}\right]$-glucose was determined by GC-MS (QP2010, coupled with GC 2010; Shimadzu, Duisburg, Germany) to calculate eGP as described (Hammon et al., 2008; Steinhoff-Wagner et al., 2011). Whole blood in $\mathrm{K}_{3}$ EDTA tubes collected before and at regular intervals between 60 and 240 min after the initiation of tracer infusion was used to isolate $\mathrm{CO}_{2}$ for the measurement of the ${ }^{13} \mathrm{C} /{ }^{12} \mathrm{C}$ ratio by isotope ratio mass spectrometry and calculate GOx (Hammon et al., 2008; Weber et al., 2016).

Additional blood samples were collected hourly until $6 \mathrm{~h}$ after the initiation of tracer infusion to measure concentrations of plasma glucose, BHB, insulin, glucagon, cortisol, and GH. Blood samples were treated, and measurements were performed as described above.

\section{Statistical Analyses}

Statistical analyses were performed with SAS for Windows, release 9.4 (SAS Institute Inc., Cary, NC). The basal concentrations of plasma metabolites and hormones and gene expression in the liver were analyzed by repeated-measures ANOVA using the MIXED procedure and a model including EFA (levels: yes, no), CLA (levels: yes, no), time (level: d relative to calving), block (levels: 1-5), and the respective interactions as fixed effects and the calving interval and projected milk yield during the second lactation as covariates. Repeated measures of each cow were considered by using the repeated statement of the MIXED procedure with a compound symmetry covariance structure. The ranges of the repeated variable time for the metabolite and hormone data were as follows: AP (d 63-10
AP), the transition period (d 21 AP to $28 \mathrm{PP}$ ), PP (d 1-56 PP), and the entire period (d $63 \mathrm{AP}$ to $56 \mathrm{PP}$ ). The data were analyzed separately for each observation period. The liver glycogen concentration and gene expression data were analyzed considering only the entire period (d $63 \mathrm{AP}$ to $63 \mathrm{PP}$ ). The concentrations of plasma metabolites and hormones during profiling were analyzed by repeated-measures ANOVA using the MIXED procedure and a model including EFA (levels: yes, no), CLA (levels: yes, no), d (levels: d 28 AP, d 21 PP), hour (levels: 0-6 h), block (levels: $1-5$ ), and the respective interactions as fixed effects as well as the calving interval and projected milk yield during the second lactation as covariates. Due to large differences between d $28 \mathrm{AP}$ and d $21 \mathrm{PP}$, the data on whole-body glucose metabolism determined via the tracer technique were analyzed separately for d 28 AP and d 21 PP by ANOVA using the MIXED procedure and with a model containing EFA (levels: yes, no), CLA (levels: yes, no), block (levels: 1-5), and the respective interactions as fixed effects as well as the calving interval and projected milk yield during the second lactation as covariates. For the analysis at d 21 PP, milk yield on the day of measurement was used as an additional covariate. The differences over time between d 28 AP and d $21 \mathrm{PP}$ were calculated in a separate model by repeated-measures ANOVA. The least squares means (LSM) and their standard errors were computed for each fixed effect in the ANOVA models to display the results. All group differences of these LSM were tested using the Tukey-Kramer procedure. The SLICE statement of the MIXED procedure was used to assess the partitioned analyses of the LSM for interactions. All differences with $P<0.05$ were considered significant.

\section{RESULTS}

\section{Plasma Glucose and Related Hormones as well as Whole-Body Glucose Metabolism}

The plasma glucose concentration (Figure 1A) peaked $(P<0.001)$ on d 28 AP, dropped down with calving, and slightly increased thereafter $(P<0.001)$. On d $21 \mathrm{PP}$, plasma glucose concentration indicated a CLA effect $(P<0.05)$ and was $15 \%$ higher in CLA-treated than in EFA-treated cows $(P<0.05)$. During the 6 -h time profile, plasma glucose concentration remained constant on d $28 \mathrm{AP}$, but on d $21 \mathrm{PP}$, glucose concentration slightly decreased $(P<0.001)$ with a $17 \%$ higher $(P<0.05)$ glucose concentration in EFA+CLA than in EFA after $5 \mathrm{~h}$ and a 11 to $12 \%$ higher glucose concentration $(P<$ $0.05)$ in CLA than in non-CLA-treated cows 5 and $6 \mathrm{~h}$ after beginning of the measurement (Figure 1B). The plasma BHB concentration (Figure 1C) increased after 
calving, with an EFA effect on d $21 \mathrm{PP}(P<0.05)$ and a $75 \%$ higher concentration $(P=0.05)$ in EFA+CLA than in CTRL. Accordingly, the BHB concentration during profiling was lower $(P<0.001)$ on d 28 AP than on $\mathrm{d} 21 \mathrm{PP}$ and declined $(P<0.001)$ on $\mathrm{d} 21 \mathrm{PP}$ in CLA and EFA+CLA (Figure 1D). During plasma profiling on d 21, PP BHB concentration was $43 \%$ higher $(P<0.05)$ in EFA- than in non-EFA-treated cows, $70 \%$ higher $(P<0.05)$ in EFA+CLA than in CTRL at the beginning of the profiling, and $80 \%$ higher $(P<0.05)$ in EFA+CLA and EFA than in CTRL at $1 \mathrm{~h}$ after the start.

The plasma insulin concentration increased after drying off $(P<0.001)$ and decreased $(P<0.001)$ markedly after calving in all groups (Figure $2 \mathrm{~A}$ ). Plasma insulin was 26 to $44 \%$ higher $(P<0.05)$ in CLA treated than non-CLA cows from d $21 \mathrm{AP}$ to d $1 \mathrm{PP}$, as well as on d
$21 \mathrm{PP}$, and was highest $(P<0.05)$ on $\mathrm{d} 1 \mathrm{PP}$ in CLA. During profiling, plasma insulin was lower $(P<0.05)$ $\mathrm{PP}$ than AP and dropped $(P<0.001)$ after beginning within the first hours AP and PP (Figure 2B). On d 28 AP, plasma insulin was $24 \%$ lower $(P<0.05)$ at the beginning of the profiling in EFA than in non-EFA groups, and on d $21 \mathrm{PP}$ was $79 \%$ higher $(P<0.05)$ in CLA than in the non-CLA groups at the beginning. In addition, there was a trend $(P=0.1)$ on d $21 \mathrm{PP}$ for $57 \%$ higher plasma insulin in CLA than non-CLA cows across all time points. There were no significant differences over time or treatment effects for basal glucagon concentration (Figure 2C). With respect to profiling, plasma glucagon concentration increased $(P<0.05)$ in non-CLA cows but decreased $(P<0.05)$ in CLA from d 28 AP to d 21 PP (Figure 2D). On d 21, PP plasma glucagon was 21 to $34 \%$ lower $(P<0.05)$ in CLA than

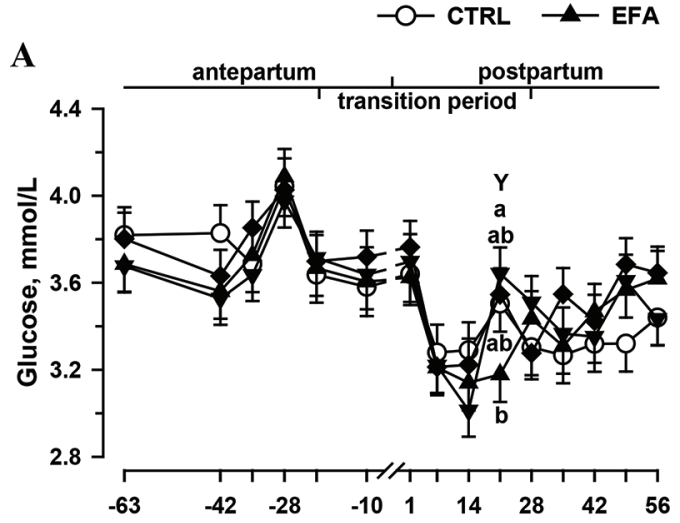

C

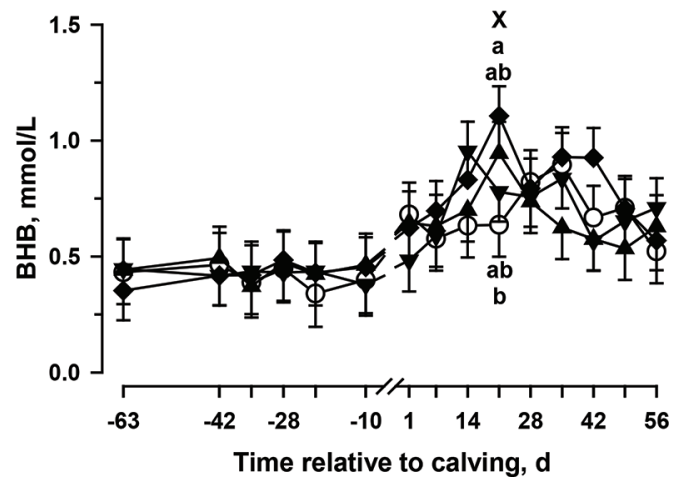

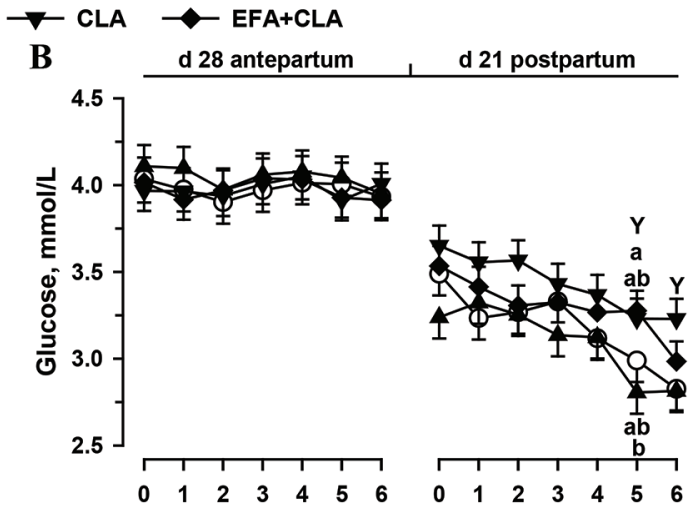

D

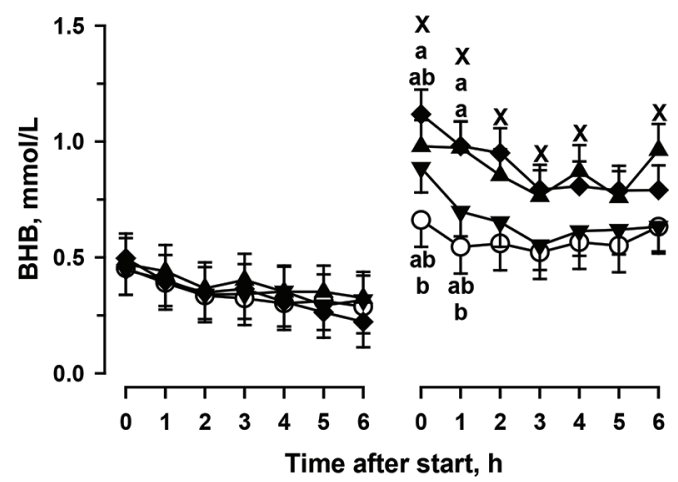

Figure 1. Concentrations of plasma glucose (A, B) and BHB (C, D) during the entire study (A, C) and during 6-h metabolic profiling with feed withdrawal on d 28 antepartum and d 21 postpartum (B, D) in cows supplemented daily with coconut oil $($ CTRL; n = 9), linseed and safflower oil (EFA; $\mathrm{n}=9$ ), Lutalin (CLA; cis-9,trans-11 and trans-10, cis-12 CLA; $\mathrm{n}=10)$, and EFA+CLA ( $\mathrm{n}=10)$ from d 63 antepartum until d 56 postpartum. Data are presented as LSM \pm SE; LSM with different letters $(\mathrm{a}, \mathrm{b})$ differ $(P<0.05)$ at the respective time point. $\mathrm{X}=\mathrm{EFA}$ effect at the respective time point. $\mathrm{Y}=\mathrm{CLA}$ effect at the respective time point. Statistically significant $(P<0.05)$ effects of the basal plasma glucose concentration during the antepartum (time), transition (time), and postpartum (time) periods, during the entire study (time), and during profiling (day, hour, EFA $\times$ day, CLA $\times$ day). Statistically significant $(P<0.05)$ effects for the basal plasma BHB concentration during the transition (time) and postpartum (time) periods, during the entire study (time), and during profiling (day, hour, EFA $\times$ day). 
in the non-CLA groups from 4 to $6 \mathrm{~h}$ and was higher $(P$ $<0.05)$ in EFA than in EFA+CLA and CLA at 4 and $5 \mathrm{~h}$ after the beginning of blood sampling.

The glucagon/insulin and glucose/insulin ratios increased after calving $(P<0.01)$ in all groups, were 4.5 and 3.8-fold higher $(P<0.05)$ in CTRL than in CLA during the transition period (Table 2), and peaked on d $21 \mathrm{PP}(P<0.05)$ in CTRL (data not shown). During the profiling studies, the 2 ratios were higher $(P<0.05)$ on d 21 PP than on d 28 AP (data not shown). On d 21 $\mathrm{PP}$, the glucagon/insulin ratio in all groups except for $\mathrm{EFA}+\mathrm{CLA}$ and the glucose/insulin ratio in EFA and

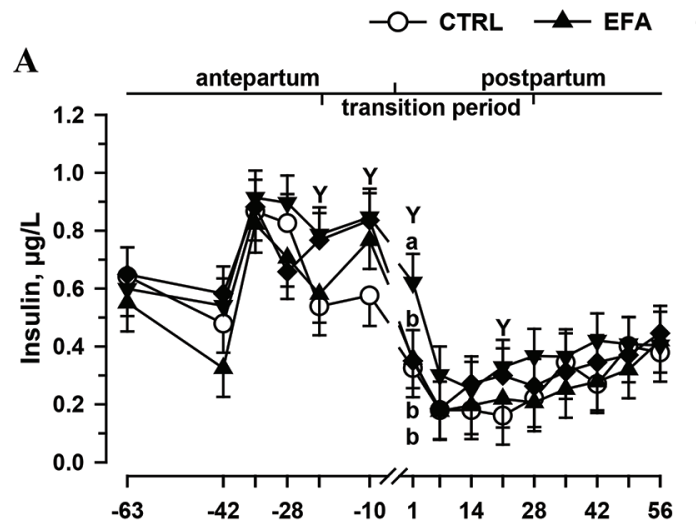

C
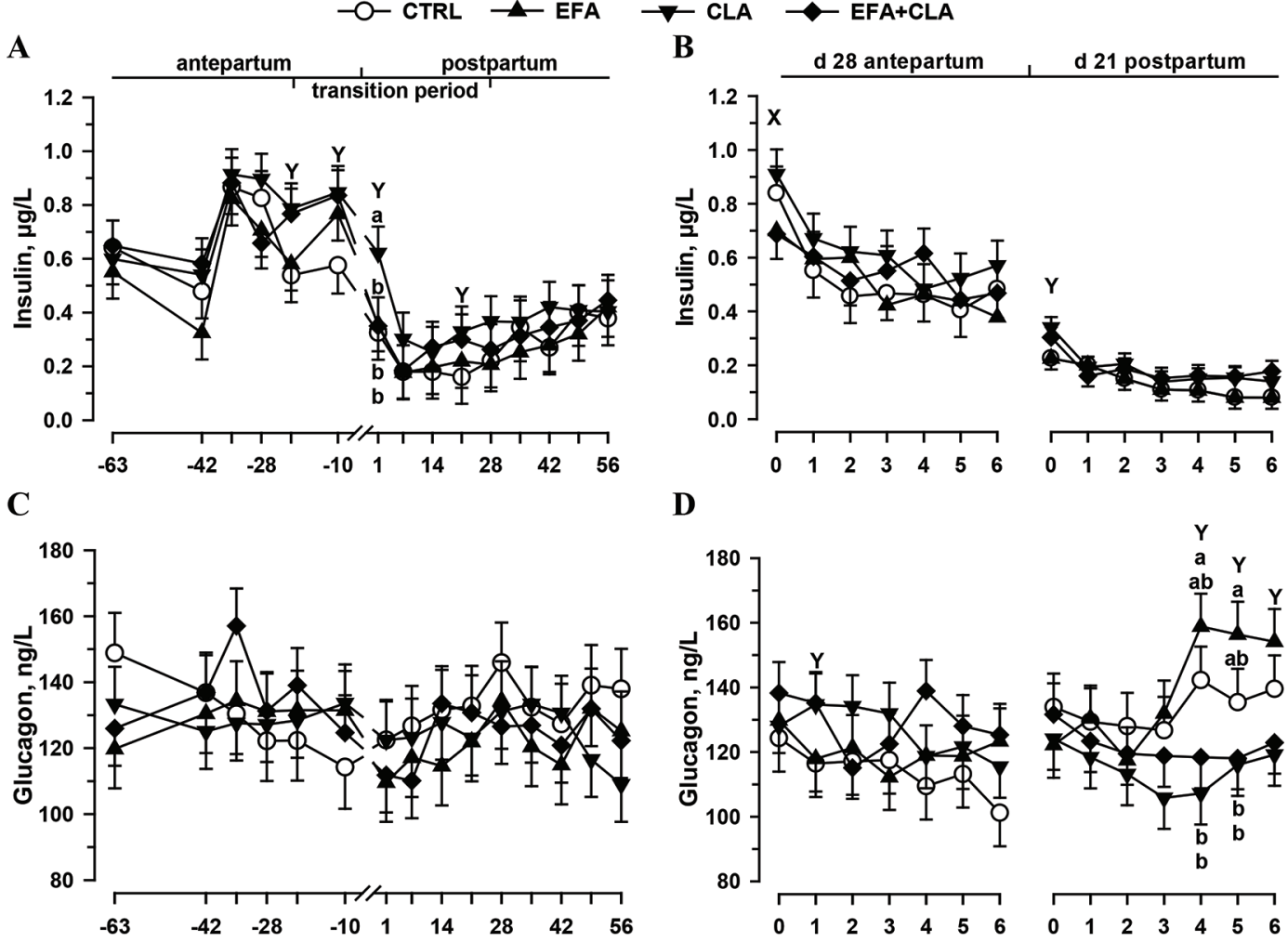

D
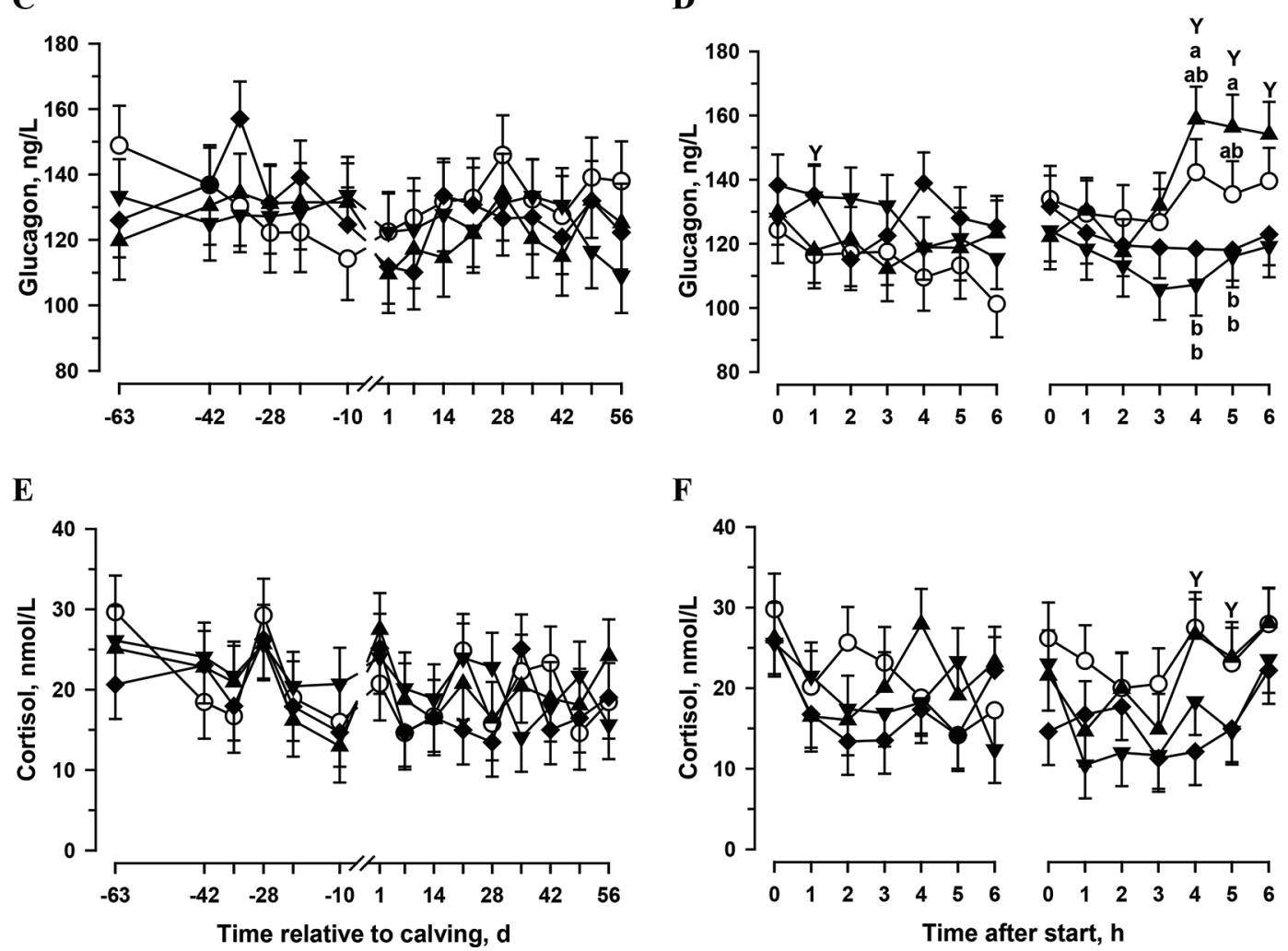

Figure 2. Concentrations of plasma insulin (A, B), glucagon (C, D), and cortisol (E, F) during the entire study (A, C, E) and during 6-h metabolic profiling with feed withdrawal on d 28 antepartum and d 21 postpartum (B, D, F) in cows supplemented daily with coconut oil $(\mathrm{CTRL} ; \mathrm{n}=9)$, linseed and safflower oil $(\mathrm{EFA} ; \mathrm{n}=9)$, Lutalin $(\mathrm{CLA} ;$ cis-9, trans-11 and trans-10, cis-12 CLA; $\mathrm{n}=10)$, and EFA+CLA $(\mathrm{n}=$ 10) from d 63 antepartum until d 56 postpartum. Data are presented as LSM \pm SE; LSM with different letters $(\mathrm{a}, \mathrm{b})$ differ $(P<0.05)$ at the respective time point. $\mathrm{X}=\mathrm{EFA}$ effect at the respective time point. $\mathrm{Y}=\mathrm{CLA}$ effect at the respective time point. Statistically significant $(P<$ 0.05) effects for the basal plasma insulin concentration during the antepartum (time), transition (time; CLA), and postpartum (time; CLA) periods, during the entire study (time) and during profiling (day, hour, day $\times$ hour). Statistically significant $(P<0.05)$ effects for the plasma glucagon concentration during profiling (day, day $\times$ hour, CLA $\times$ day, CLA $\times$ day $\times$ hour). Statistically significant $(P<0.05)$ effects for the basal plasma cortisol concentration during the antepartum (time) and transition (time) periods, during the entire study (time), and during profiling $($ CLA, CLA $\times$ day, hour; day $\times$ hour). 
CLA cows increased $(P<0.05)$ during blood sampling, and both ratios were $77 \%$ (glucagon/insulin) and $33 \%$ (glucose/insulin) lower $(P<0.05)$ in CLA than in the non-CLA groups. The glucagon/insulin ratio on $\mathrm{d} 21$ $\mathrm{PP}$ was higher $(P<0.05)$ in CTRL than in CLA and EFA + CLA and was higher $(P<0.05)$ in EFA than in $\mathrm{EFA}+\mathrm{CLA}$ (LSM $\pm \mathrm{SE}$ for CTRL, EFA, CLA, and EFA+CLA were $8.46 \pm 0.91,7.27 \pm 0.89,5.11 \pm 0.84$, and $3.76 \pm 0.84 \mathrm{~mol} / \mathrm{mol}$, respectively). The glucose/ insulin ratio was higher $(P<0.05)$ in CTRL than in $\mathrm{EFA}+\mathrm{CLA}$ on $\mathrm{d} 21 \mathrm{PP}(\mathrm{LSM} \pm \mathrm{SE}$ for CTRL, EFA, CLA, and EFA+CLA were $681 \pm 78,518 \pm 75,505 \pm$ 72 , and $394 \pm 71 \mathrm{mmol} / \mathrm{nmol}$, respectively). The glucose/glucagon ratio decreased $(P<0.05)$ after calving in EFA+CLA but indicated no further time and treatment differences (data not shown). During the profiling studies, the glucose/glucagon ratio was higher $(P<$ $0.05)$ on d 28 AP than on d $21 \mathrm{PP}$ (data not shown). On d $21 \mathrm{PP}$, the glucose/glucagon ratio was higher $(P$ $<0.05)$ in CLA than in EFA and was higher $(P<0.05)$ in CLA than non-CLA-treated groups (LSM $\pm \mathrm{SE}$ for CTRL, EFA, CLA, and EFA+CLA were $88.7 \pm 6.9$, $83.5 \pm 6.6,109.1 \pm 6.3$, and $98.8 \pm 6.2 \mathrm{mmol} / \mathrm{nmol}$, respectively).

Plasma cortisol varied AP $(P<0.001)$ and during the transition period $(P<0.05)$ with peaks $(P<0.05$ or less) at d $28 \mathrm{AP}$ and d 1 after calving but without differences between groups (Figure $2 \mathrm{E}$ ). The 6 -h profile of the plasma cortisol concentration indicated no differences over time between AP and PP, but plasma cortisol was $60 \%$ lower $(P<0.05)$ on d $21 \mathrm{PP}$ in CLA than in the non-CLA cows, especially 4 and $5 \mathrm{~h}$ after the beginning of blood sampling (Figure 2F).

The results for eGP and GOx are shown in Table 3. Endogenous glucose production increased from AP to PP $(P<0.001)$ by $63 \%$, indicating an EFA and CLA effect with $6 \%$ elevated eGP $(P<0.05)$ in EFA compared with the non-EFA groups and $11 \%$ decreased eGP $(P<0.01)$ in CLA compared with the non-CLA groups and was higher $(P<0.05)$ in EFA than in CLA $(18 \%)$ and EFA+CLA cows $(12 \%)$ on d $21 \mathrm{PP}(P<$ $0.05)$. On the other hand, GOx decreased from $d 28$ AP to d $21 \mathrm{PP}(P<0.001)$ by $130 \%$ and was $38 \%$ lower in CLA cows than in CTRL cows PP $(P<0.05)$. The percentage of GOx relative to eGP declined $(P<$ 0.001 ) from d 28 AP to d 21 PP 3.6-foald, indicating an EFA $\times$ CLA interaction $(P=0.05)$ on d $21 \mathrm{PP}$. There was a trend $(P<0.1)$ of a decreased GOx/eGP ratio in EFA and CLA compared with CTRL cows.

\section{Somatotropic Axis in Blood Plasma}

The growth hormone concentration in blood plasma increased during early lactation $(P<0.05)$ and was

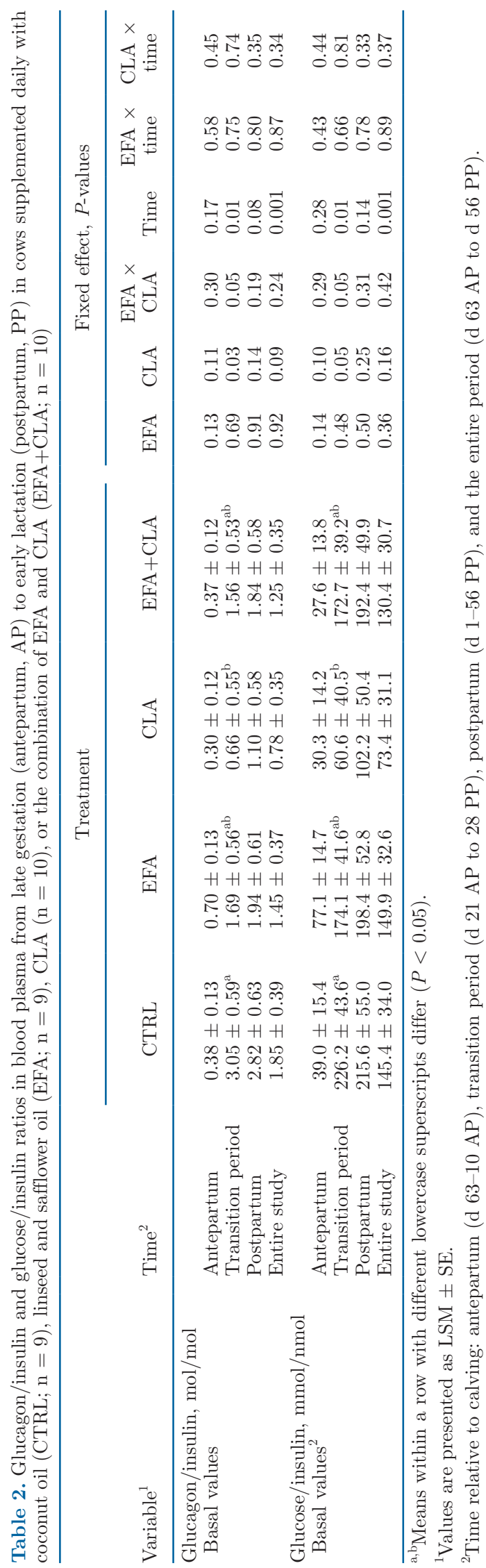


Table 3. Endogenous glucose production (eGP) and glucose oxidation (GOx) on d 28 antepartum (AP) and d 21 postpartum (PP) in cows supplemented daily with coconut oil (CTRL; $\mathrm{n}=9$ ), linseed and safflower oil (EFA; $\mathrm{n}=9$ ), CLA ( $\mathrm{n}=10$ ), or the combination of EFA and CLA $(\mathrm{EFA}+\mathrm{CLA} ; \mathrm{n}=10)$ during late gestation and early lactation

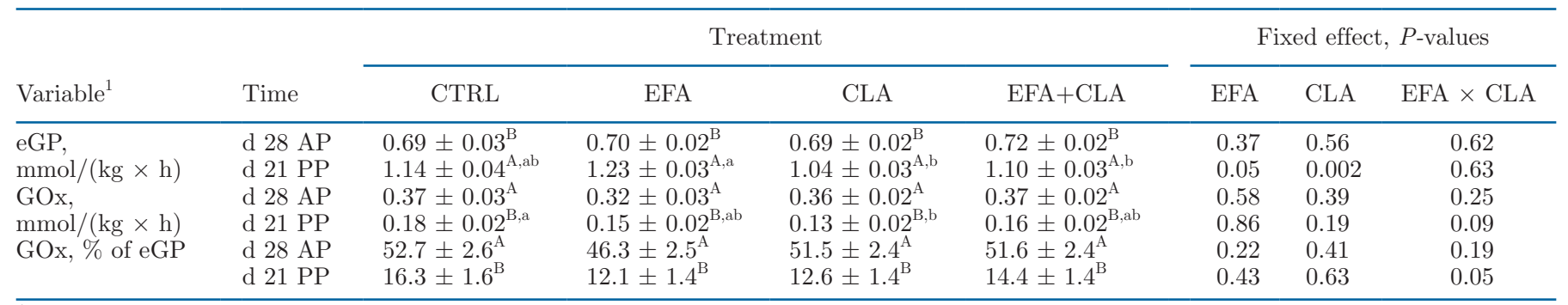

\footnotetext{
${ }^{\mathrm{A}, \mathrm{B}}$ Means of a particular parameter within a column with different uppercase superscripts differ $(P<0.05)$.

${ }^{\mathrm{a}, \mathrm{b}}$ Means within a row with different lowercase superscripts differ $(P<0.05)$.

${ }^{1}$ Values are presented as LSM $\pm \mathrm{SE}$.
}

$49 \%$ higher $(P<0.05)$ in CLA than in non-CLA cows on d $49 \mathrm{PP}$ (Figure $3 \mathrm{~A}$ ). The 6-h time profile of plasma GH showed only minor changes by d, with slightly higher GH concentrations being observed on d $21 \mathrm{PP}$ than d 28 AP, especially in EFA (Figure 3B). On d 21 $\mathrm{PP}$, plasma GH increased $(P<0.05)$ in EFA+CLA and showed a tendency to increase $(P<0.1)$ in EFA up to $2 \mathrm{~h}$ after the beginning of blood sampling. At $2 \mathrm{~h}$ on d 21 PP, 87\% higher plasma GH was observed in EFA than in non-EFA cows, and plasma $\mathrm{GH}$ was higher $(P$ $<0.05)$ in EFA+CLA than in CTRL and EFA. The plasma IGF-I concentration was highest $(P<0.05)$ on d $35 \mathrm{AP}$ and decreased $(P<0.001)$ in all groups during the transition period until d $14 \mathrm{PP}$ (Figure 3C). The plasma IGF-I results indicated an EFA effect $(P$ $<0.05$ ) on d $42 \mathrm{AP}$, with $46 \%$ higher concentrations in CLA than in EFA cows $(P<0.05)$. Beginning on d 28 AP in the CLA group and d 21 AP in the EFA group, plasma IGF-I was higher $(P<0.05)$ than in CTRL until calving (25-46\% difference). After calving, plasma IGF-I was 25 to $37 \%$ higher $(P<0.05)$ at several time points in CLA than in non-CLA cows, and at the end of the study, plasma IGF-I was higher $(P<0.05)$ in the CLA than in CTRL.

The concentration of plasma IGFBP-2 increased $(P$ $<0.05)$ from the AP to the PP period by $158 \%$, and the results indicated a 35 to $43 \%$ decreased plasma concentration $(P<0.05)$ with CLA treatment on $\mathrm{d}$ $42 \mathrm{AP}$ and $\mathrm{d} 56 \mathrm{PP}$ and a lower $(P<0.05)$ concentration in the CLA group than in the EFA group on $\mathrm{d} 56$ PP (Figure 4A). The plasma IGFBP-3 concentration decreased $(P<0.001)$ during AP by $46 \%$, reached the lowest concentration on $\mathrm{d} 1 \mathrm{PP}$, and slowly increased $(P<0.001)$ thereafter (Figure 4B). Elevated concentrations $(P<0.05)$ were observed on $\mathrm{d} 42$ and $21 \mathrm{AP}$ and $\mathrm{d} 28$ and $56 \mathrm{PP}$ in CLA (by 23-34\%) and on d 21 AP in EFA groups (by 23\%). Plasma IGFBP-3 was higher $(P<0.05)$ in EFA+CLA than in CTRL on d 21
AP and higher $(P<0.05)$ in CLA than in CTRL on $\mathrm{d}$ $28 \mathrm{PP}$. The concentration of IGFBP-3 was $23 \%$ higher $(P<0.05)$ in CLA than in non-CLA cows during the transition and PP periods. The IGFBP-3/-2 ratio was 60 to $170 \%$ higher $(P<0.05)$ in CLA than in CTRL and EFA during the entire study, reached the lowest point on d $14 \mathrm{PP}$, and increased $(P<0.001)$ thereafter (Figure $4 \mathrm{C})$. A decreasing effect by $32 \%(P<0.05)$ of EFA treatment was observed on d $42 \mathrm{AP}$. The concentration of plasma IGFBP-4 slightly decreased AP $(P<$ $0.01)$ and was higher $(P<0.05)$ in CLA than in the non-CLA groups on d $56 \mathrm{PP}$ by $32 \%$ (Figure $4 \mathrm{D}$ ).

\section{Liver Glycogen Concentration and Gene Expression Involved in Glucose Metabolism and the Somatotropic Axis}

One cow of the CLA group was not included in the analyses due to failure to obtain liver samples by biopsies. The hepatic glycogen content decreased at calving $(P<0.001)$ by $58 \%$ and was $16 \%$ higher $(P<0.05)$ in CLA than in non-CLA-treated cows on d 28 PP (Figure 5A). The abundance of $P C$ mRNA increased $(P<$ $0.001) 3.7$-fold on d $1 \mathrm{PP}$ and was increased up to $100 \%$ $(P<0.05)$ in CTRL on d 1 , indicating a decreasing effect $(P<0.05)$ of EFA and CLA treatment (Figure 5B). The $P C K 1$ mRNA abundance was lower $(P<0.05)$ AP than $\mathrm{PP}$ and increased 3-fold with ongoing lactation $(P<0.001)$, with $42 \%$ lower expression $(P<0.05)$ being observed in EFA than non-EFA-treated cows on d $28 \mathrm{PP}$ (Figure 5C). The abundance of PCK2 mRNA increased at calving $(P<0.001)$ by $32 \%$, was lower in EFA +CLA than in CTRL $(P<0.05)$ on $\mathrm{d} 1 \mathrm{PP}$ and was highest $(P<0.05)$ in CLA on d $28 \mathrm{PP}$ (Figure 5D). The abundance of $P C K 2 \mathrm{mRNA}$ indicated a decreasing effect of EFA treatment $(P<0.05)$ on d 1 and $28 \mathrm{PP}$ by 37 and $42 \%$, respectively. The abundance of $G 6 P C$ and $P C C A$ mRNA increased $(P<0.01)$ after d 1 PP by 100 

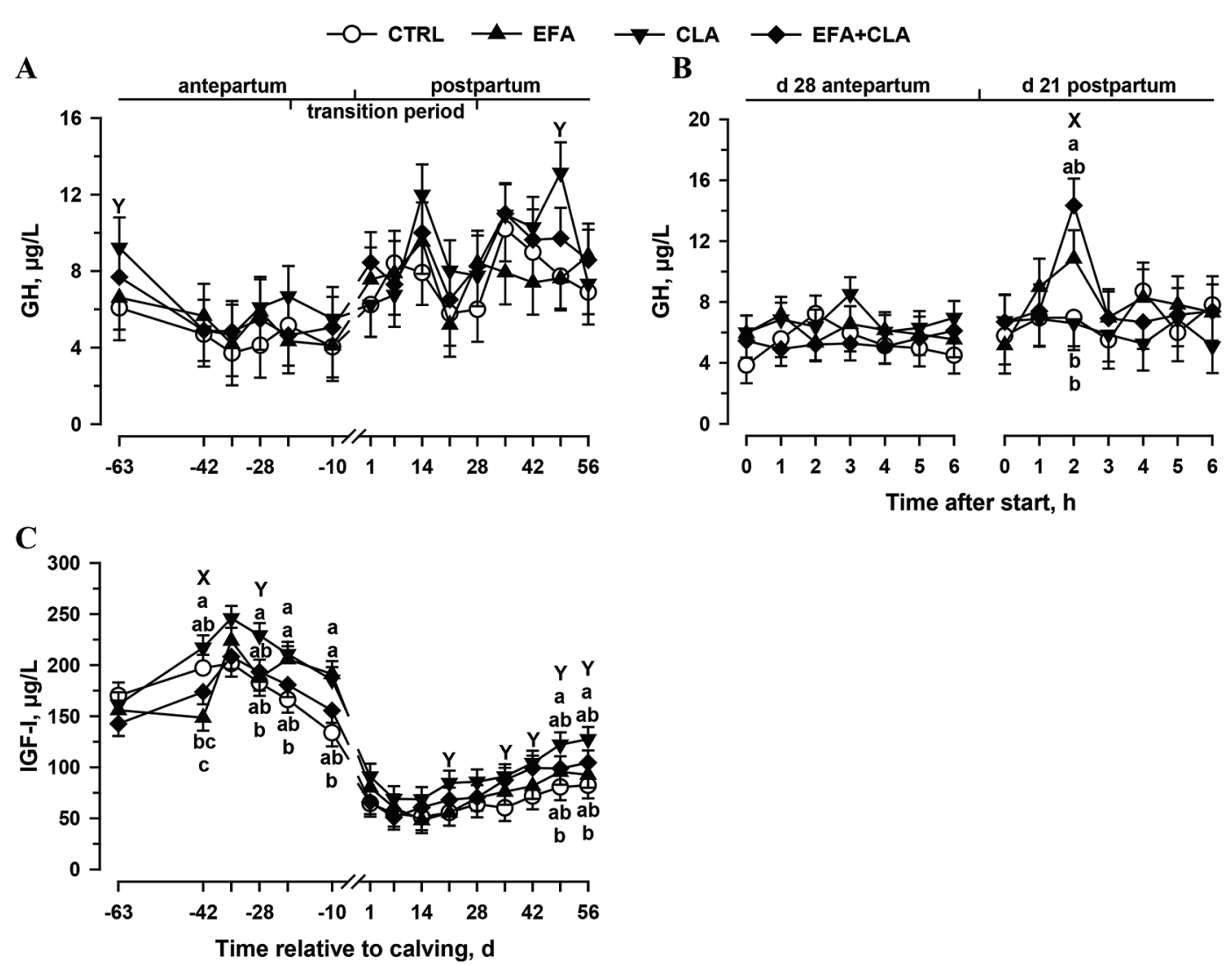

Figure 3. Concentrations of plasma of growth hormone (GH; A) and IGF-I (C) during the entire study as well as GH (B) during 6-h metabolic profiling with feed withdrawal on d 28 antepartum and d 21 postpartum in cows supplemented daily with coconut oil (CTRL; $\mathrm{n}=9$ ), linseed and safflower oil (EFA; $\mathrm{n}=9$ ), Lutalin (CLA; cis-9, trans-11 and trans-10, cis-12 CLA; $\mathrm{n}=10)$, and EFA+CLA ( $\mathrm{n}=10)$ abomasally from d 63 antepartum until d 56 postpartum. Data are presented as LSM \pm SE; LSM with different letters $(a, b, c)$ differ $(P<0.05)$ at the respective time point. $\mathrm{X}=\mathrm{EFA}$ effect at the respective time point. $\mathrm{Y}=\mathrm{CLA}$ effect at the respective time point. Statistically significant $(P<0.05)$ effects for the concentration of plasma GH during the antepartum (time), transition (time), and postpartum (time) periods, during the entire study (time), and during profiling (day, EFA $\times$ day). Statistically significant $(P<0.05)$ effects for the concentration of plasma IGF-I during the antepartum (time; EFA $\times$ time; EFA $\times$ CLA $\times$ time), transition (time; EFA $\times$ CLA; EFA $\times$ CLA $\times$ time), and postpartum $($ time; CLA) periods and during the entire study (time; EFA $\times$ time; EFA $\times$ CLA $\times$ time).

and $133 \%$, respectively (Figure $5 \mathrm{E}$ and F). On d $28 \mathrm{PP}$, the abundance of $P C C A$ and $G 6 P C$ was 58 and $43 \%$ lower $(P<0.01)$ in EFA than in the non-EFA groups, with higher expression $(P<0.05)$ being observed in CLA than in EFA+CLA $(G 6 P C)$ or EFA (PCCA). The mRNA abundance of HMGCS2 increased 2-fold after calving $(P<0.001)$, was 2 -fold higher $(P<0.05)$ on $\mathrm{d}$ $28 \mathrm{PP}$ in CLA than in EFA+CLA and was decreased $53 \%(P<0.05)$ by EFA treatment (Figure $5 \mathrm{G})$.

The abundance of GHR1A and IGF1 was lowest $(P<0.05)$ on $\mathrm{d} 1 \mathrm{PP}$ and increased 3 -fold up to $\mathrm{d}$ $63 \mathrm{PP}$, respectively (Figure $6 \mathrm{~A}, \mathrm{~B}$ ). The abundance of $G H R 1 A$ showed an increasing tendency $(P<0.1)$ by $75 \%$ on $\mathrm{d} 63 \mathrm{PP}$ in EFA+CLA than in CTRL. In addition, GHR1A mRNA showed a tendency to be stimulated $78 \%(P<0.1)$ by CLA treatment on $\mathrm{d} 28$ $\mathrm{PP}$ and $36 \%$ by EFA on $\mathrm{d} 63 \mathrm{PP}$. The abundance of $I G F B P 2$ increased 2.5 -fold $(P<0.001)$ from AP to the end of the study, with lower expression being observed in EFA on d $28 \mathrm{PP}(P<0.01$; by $60 \%)$ and in CLA $(P$ $<0.001$ ) on $\mathrm{d} 1$ and $\mathrm{d} 63 \mathrm{PP}$ by 56 and $47 \%$ (Figure $6 \mathrm{C})$. The IGFBP2 mRNA abundance was higher $(P<$ $0.05)$ on $d 28 \mathrm{PP}$ in CLA than in EFA+CLA and was higher $(P<0.05)$ on d 63 PP in EFA than in CLA and EFA + CLA. The abundance of IGFBP3 was highest $(P$ $<0.001$ ) on d $63 \mathrm{PP}$ and was decreased $49 \%$ by EFA treatment on d $21 \mathrm{AP}$ (Figure 6D). The abundance of INSR mRNA slightly increased $(P<0.001)$ throughout the experimental period and was 47 and $63 \%$ lower $(P<0.05)$ in EFA than in non-EFA groups on $d 1$ and $28 \mathrm{PP}$ (Figure 6E). On d $28 \mathrm{PP}$, INSR mRNA abundance was higher $(P<0.05)$ in CLA than in EFA and EFA+CLA. The INSR mRNA abundance across all time points was $52 \%$ higher in the CLA $(P<0.05)$ and showed a tendency to be $44 \%$ higher in CTRL $(P$ $=0.07)$ than in EFA. 

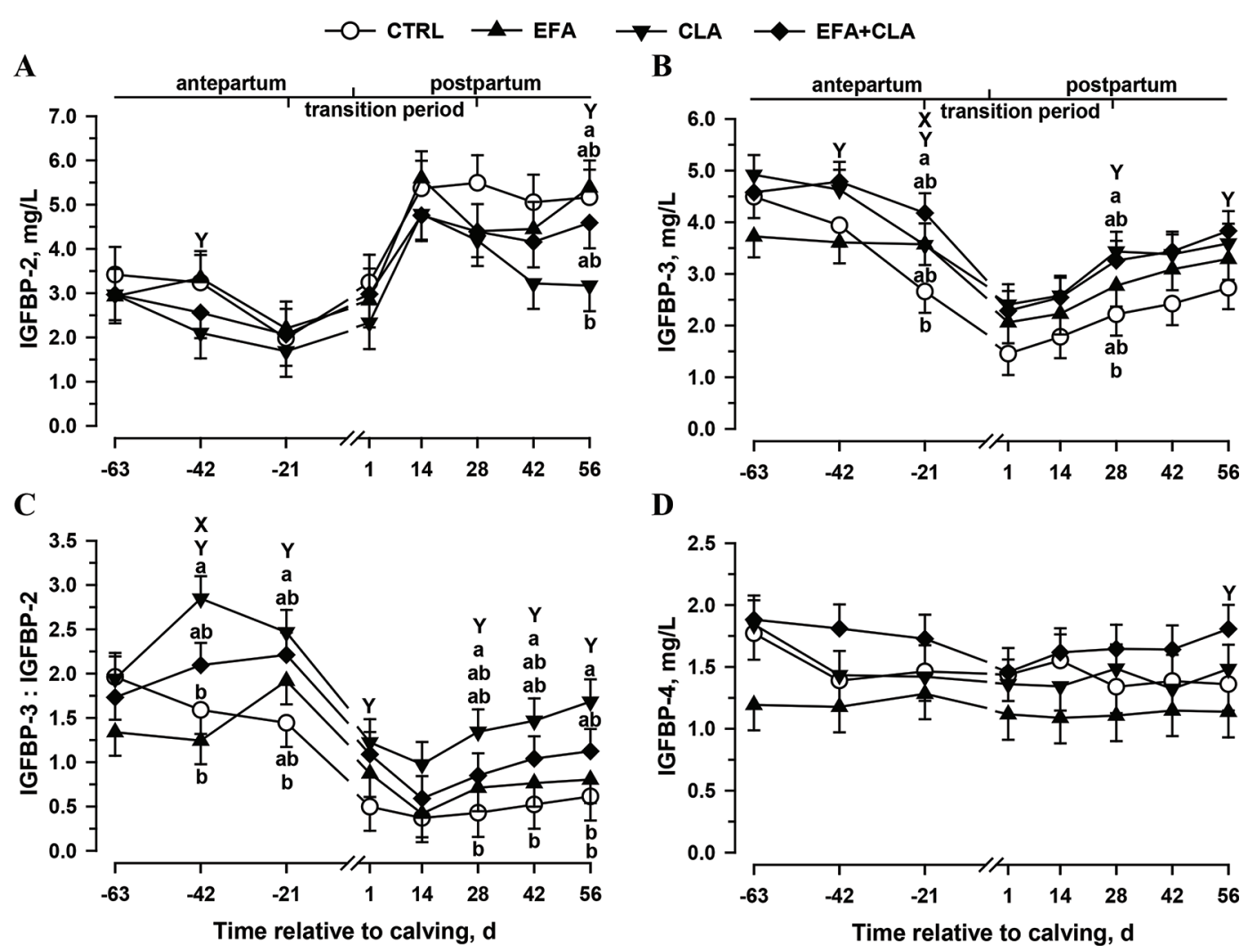

Figure 4. Concentrations of plasma IGF-binding protein 2 (IGFBP-2; A), IGFBP-3 (B), the calculated ratio (IGFBP-3: IGFBP-2; C) and IGFBP-4 (D) in cows supplemented daily with coconut oil (CTRL; $\mathrm{n}=9$ ), linseed and safflower oil (EFA; $\mathrm{n}=9$ ), Lutalin (CLA; cis-9, trans-11 and trans-10,cis-12 CLA; $\mathrm{n}=10)$, and EFA+CLA $(\mathrm{n}=10)$ abomasally from d 63 antepartum until d 56 postpartum. Data are presented as LSM $\pm \mathrm{SE}$; LSM with different letters $(\mathrm{a}, \mathrm{b})$ differ $(P<0.05)$ at the respective time point. $\mathrm{X}=\mathrm{EFA}$ effect at the respective time point. $\mathrm{Y}=\mathrm{CLA}$ effect at the respective time point. Statistically significant $(P<0.05)$ effects for the concentration of plasma IGFBP-2 during the antepartum (time), transition (time), and postpartum (time) periods and during the entire study (time). Statistically significant $(P<0.05)$ effects for the concentration of plasma IGFBP-3 during the antepartum (time; EFA $\times$ time), transition (time; CLA), and postpartum (time; CLA) periods and during the entire study (time; CLA; EFA $\times$ time). Statistically significant $(P<0.05)$ effects for the IGFBP-3/-2 ratio during the antepartum (CLA; CLA $\times$ time), transition (time; CLA), and postpartum (time; CLA) periods and during the entire study (time; CLA). Statistically significant $(P<0.05)$ effects for the concentration of plasma IGFBP-4 during the antepartum period (time; EFA $\times$ time) and during the entire study (time).

\section{DISCUSSION}

\section{Glucose Metabolism, Endocrine Regulation, and Hepatic mRNA Abundance}

The metabolic changes in terms of decreased glucose and increased BHB concentrations in dairy cows during transition followed the expectations resulting from previously described findings (Hammon et al., 2009, Gross et al., 2011a, Weber et al., 2013b). The rates of eGP and GOx measured in this study were consistent with recently presented data from our group (Hammon et al., 2008; Hötger et al., 2013; Weber et al., 2016). The increase in eGP on d $21 \mathrm{PP}$ compared with d $28 \mathrm{AP}$ ensured an adequate glucose supply to the mammary gland for milk production (Aschenbach et al., 2010). In addition, whole-body GOx and the ratio of GOx to eGP decreased with the onset of lactation, which increased the availability of glucose for milk production (Drackley et al., 2001).

We observed only minor differences in the basal plasma glucose concentration because of EFA supplementation, which was consistent with previous studies (Zachut et al., 2010; Mach et al., 2013; do Prado et al., 2016). Interestingly, the present study revealed an elevated concentration of plasma BHB due to EFA treatment on d $21 \mathrm{PP}$ in basal blood samples and during hourly measurements. Previous investigations of the effect of n-3 FA supplementation in dairy cows on the plasma BHB concentration showed no changes or even decreased plasma BHB in early lactation (Mach et al., 2013; do Prado et al., 2016). On d 21 PP, the basal plasma glucose concentration and the concentration during profiling were lowest in EFA cows. A shortage of glucose availability for milk production is associated with elevated plasma nonesterified FA (NEFA) and 


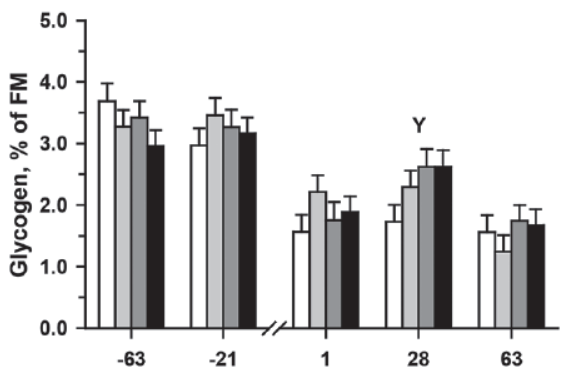

C

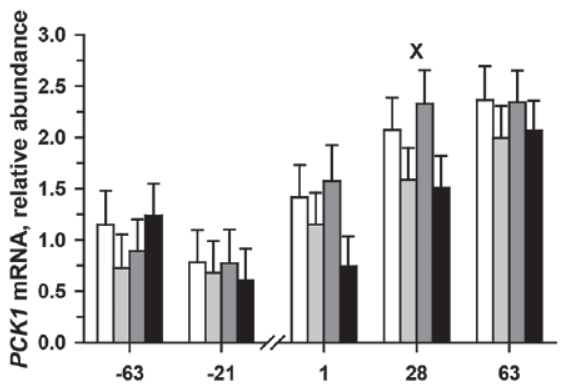

E

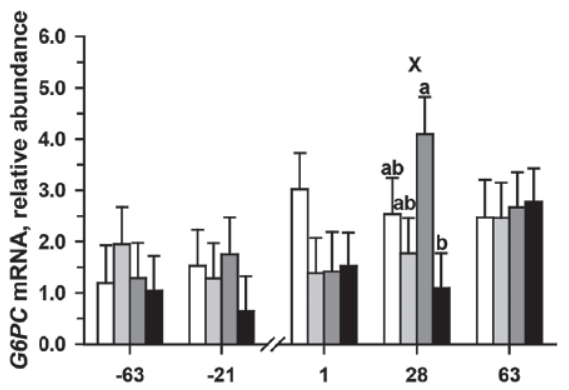

G

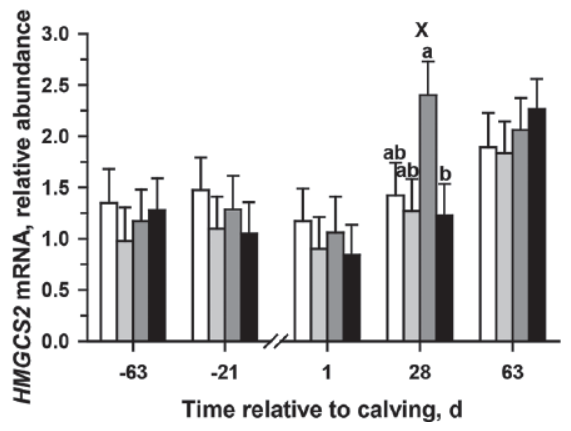

B

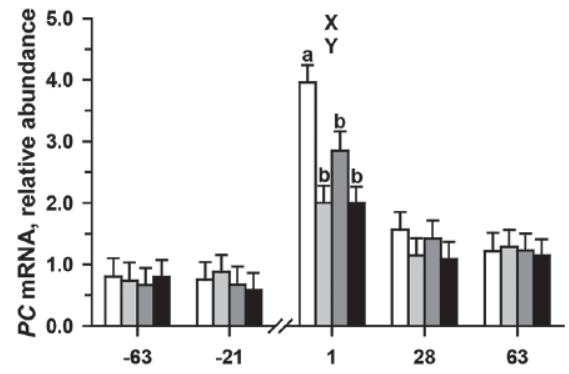

D

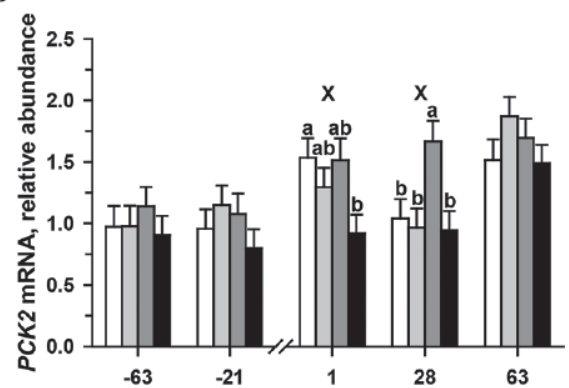

F

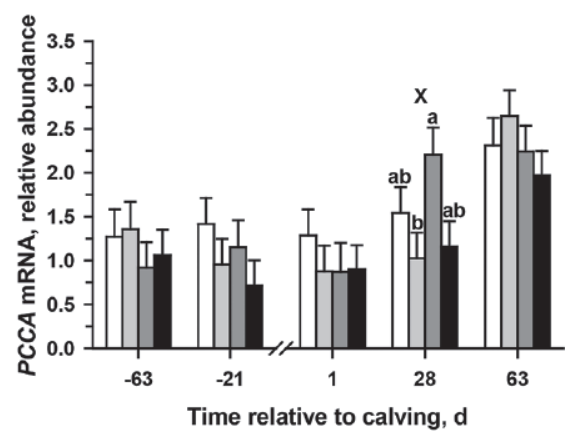

Figure 5. Liver glycogen concentration (A) and relative hepatic mRNA expression of pyruvate carboxylase $(P C$; B), cytosolic phosphoenolpyruvate carboxykinase $(P C K 1 ; \mathrm{C})$, mitochondrial phosphoenolpyruvate carboxykinase $(P C K 2 ; \mathrm{D})$, glucose-6-phosphatase $(G 6 P C$; E), mitochondrial propionyl-CoA carboxylase $\alpha$ chain $(P C C A ; \mathrm{F})$, and hydroxyl-methyl-glutaryl-CoA-synthase 2 (HMGCS2; G) in cows supplemented daily with coconut oil (CTRL; $\mathrm{n}=9$ ), linseed and safflower oil (EFA; $\mathrm{n}=9$ ), Lutalin (CLA; cis-9, trans-11 and trans-10; $\mathrm{n}=9$ ), and EFA + CLA $(\mathrm{n}=10)$ abomasally from d 63 antepartum until slaughter on d 63 postpartum. Data are presented as LSM \pm SE; LSM with different letters $(\mathrm{a}, \mathrm{b})$ differ $(P<0.05)$ at the respective time point. X: EFA effect at the respective time point. Y: CLA effect at the respective time point. Statistically significant $(P<0.05)$ effects on the liver glycogen concentration during the entire study (time). Statistically significant $(P<0.05)$ effects for the relative hepatic mRNA expression of $P C$ during the entire study (time; EFA; EFA $\times$ time). Statistically significant $(P<0.05)$ effects for the relative hepatic mRNA expression of $P C K 1$ during the entire study (time). Statistically significant $(P<0.05)$ effects for the relative hepatic mRNA expression of $P C K 2$ during the entire study (EFA $\times$ CLA; time). Statistically significant $(P<0.05)$ effects for the relative hepatic mRNA expression of G6PC during the entire study (time). Statistically significant $(P<0.05)$ effects for the relative hepatic mRNA expression of $P C C A$ during the entire study (time). Statistically significant $(P<0.05)$ effects for the relative hepatic mRNA expression of HMGCS2 during the entire study (time). 


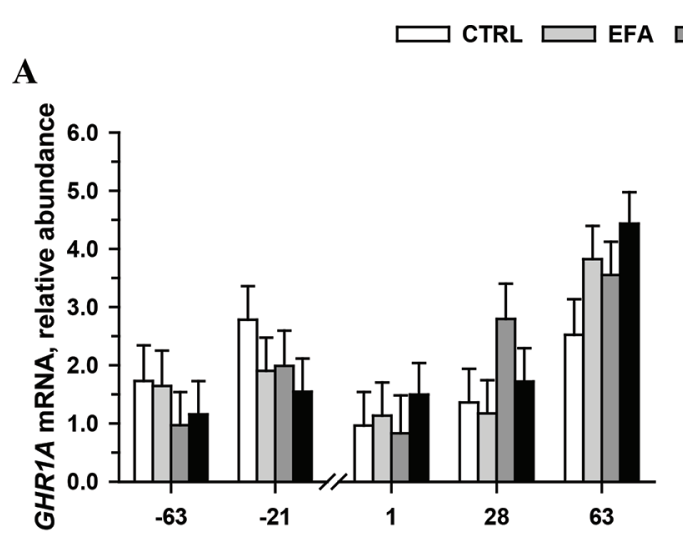

B

\section{C}

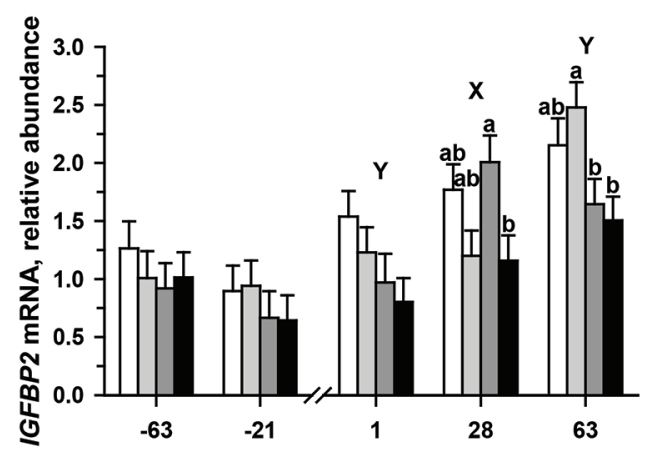

$\mathbf{E}$

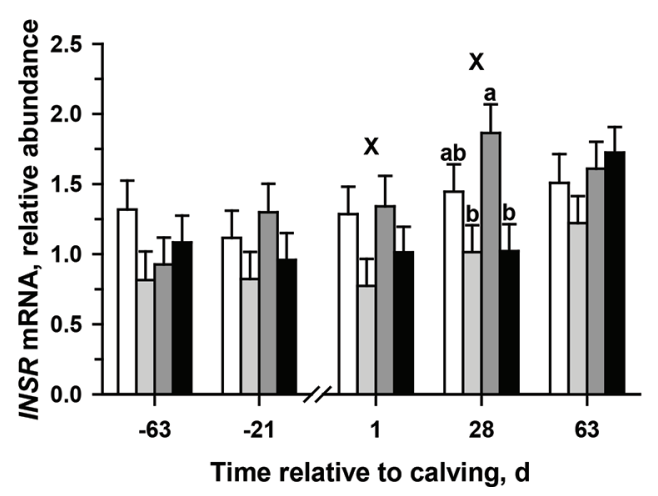

D

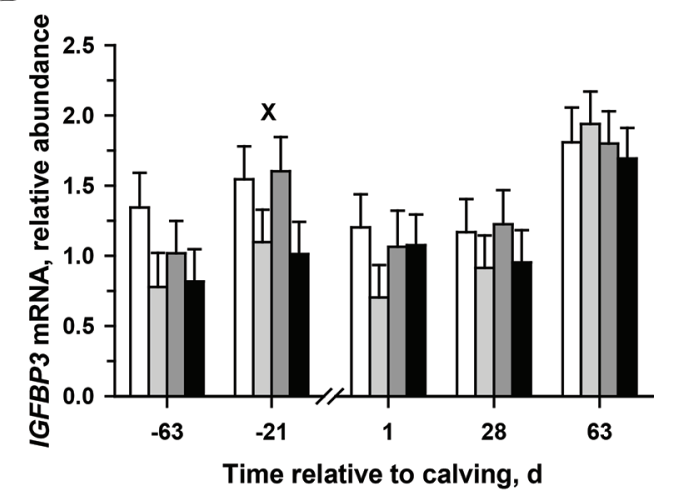

Figure 6. Relative hepatic mRNA expression of growth hormone receptor 1A (GHR1A; A), IGF-I (IGF1; B), IGF-binding protein 2 (IGFBP2; C), IGF-binding protein 3 (IGFBP3; D), and insulin receptor (INSR; E) in cows supplemented daily with coconut oil $(\mathrm{CTRL}$; $\mathrm{n}=9)$, linseed and safflower oil (EFA; $\mathrm{n}=9$ ), Lutalin (CLA cis-9,trans-11 and trans-10,cis-12 CLA; $\mathrm{n}=9$ ), and EFA+CLA ( $\mathrm{n}=10)$ abomasally from d 63 antepartum until slaughter on d 63 postpartum. Data are presented as LSM \pm SE; LSM with different letters $(\mathrm{a}, \mathrm{b})$ differ $(P<0.05)$ at the respective time point. $\mathrm{X}=\mathrm{EFA}$ effect at the respective time point. $\mathrm{Y}=\mathrm{CLA}$ effect at the respective time point. Statistically significant $(P<$ $0.05)$ effects for the relative hepatic mRNA expression of GHR1A during the entire study (time). Statistically significant $(P<0.05)$ effects for the relative hepatic mRNA expression of $I G F 1$ during the entire study (time). Statistically significant $(P<0.05)$ effects for the relative hepatic mRNA expression of IGFBP2 during the entire study (time; CLA). Statistically significant $(P<0.05)$ effects for the relative hepatic mRNA expression of IGFBP3 during the entire study (time). Statistically significant $(P<0.05)$ effects for the relative hepatic mRNA expression of INSR during the entire study (time; EFA).

BHB concentrations during early lactation (Drackley et al., 2001), and the plasma NEFA concentration on d 21 $\mathrm{PP}$ was high in EFA cows in the present study (Vogel et al., 2020). Therefore, the low plasma glucose concentration may partly explain the elevated BHB concentration observed on d 21 PP. However, eGP on d 21 PP was highest in the EFA cows, indicating counter-regulation to maintain plasma glucose concentration in EFA cows. Interestingly, a stimulatory effect of $\alpha$-linolenic acid on eGP, which was the leading FA in the EFA treatment, was observed in bovine hepatocytes (Mashek and Grummer, 2003). 
Plasma BHB was not noticeably elevated in the CTRL group at the time of calving and thereafter when compared with EFA and CLA groups. There is evidence in the literature that the medium chain fatty acids that are enriched in coconut oil lead to faster oxidation and increased plasma ketone bodies such as BHB (Dayrit, 2015), which is also seen in calves (Sato, 1994). The dosage of coconut oil administered was probably too low to detect an effect of coconut oil on plasma ketone bodies in the present study. We found an elevated plasma BHB concentration but a decreased plasma NEFA concentration and an improved energy balance in EFA+CLA cows (Vogel et al., 2020), which does not support the classical concept of an increase in the plasma BHB concentration associated with elevated plasma NEFA and an overloaded fat concentration in the liver during early lactation (Drackley et al., 2001). The elevated plasma BHB concentration in EFA+CLA was probably a consequence of milk fat depression caused by CLA (Bernal-Santos et al., 2003; Urrutia and Harvatine, 2017; Vogel et al., 2020), and not increased $\mathrm{BHB}$ production in the liver. A decreased BHB production in liver is supported by the low hepatic mRNA abundance of HMGCS2, encoding a key enzyme in ketone body synthesis, in EFA+CLA cows on d 28 PP.

Despite the higher plasma glucose concentration observed on d 21 PP, eGP was decreased by CLA treatment. The inverse relationship between plasma glucose and eGP supported our previous finding of the effect of CLA treatment on plasma glucose and whole-body glucose metabolism (Grummer and Carroll, 1991; Hötger et al., 2013). Recently published data of the present study indicated a strong milk fat depression during early lactation in CLA cows by $50 \%$ when compared with CTRL and EFA groups. (Vogel et al., 2020). The decrease in eGP due to CLA treatment indicated a decreased glucose demand for milk fat synthesis induced by trans-10,cis-12 CLA (Baumgard et al., 2000), but could also result from the more efficient use of metabolizable energy in CLA-treated cows (von Soosten et al., 2012; Hötger et al., 2013). In this context, it is noteworthy that cows supplemented only with CLA also showed a decrease in GOx and an elevated glucose/ glucagon ratio on d $21 \mathrm{PP}$ in the present study. This finding emphasizes less glucose utilization induced by CLA treatment.

Endocrine changes during the transition and early lactation periods supported the concept of alleviated glucose load by decreasing glucose utilization during the CLA treatment (Drackley et al., 2001; Reist et al., 2003; Weber et al., 2013b). An elevated insulin concentration in CLA-supplemented cows during the transition period was previously described (Saremi et al., 2014, Grossen-Rösti et al., 2018). The increased basal plasma insulin concentration and decreased glucagon to insulin and glucose to insulin ratios were consistent with the diminution of eGP after calving in CLA cows (De Koster and Opsomer, 2013; Hammon et al., 2016). Plasma cortisol was decreased in CLA groups at the end of the profiling on d $21 \mathrm{PP}$. Cortisol may act as a gluconeogenic hormone in cattle (Brockman and Laarveld, 1986) and evoke an insulin-resistant state in dairy cows (Kusenda et al., 2013; Hammon et al., 2016) and young calves (Scheuer et al., 2006). We therefore speculate that insulin sensitivity was increased in the CLA-treated groups due to decreased cortisol release in blood plasma. However, previous studies have not indicated increased insulin sensitivity under CLA treatment (Saremi et al., 2014). On the contrary, CLA treatment, especially trans-10,cis-12 CLA, caused an insulin-resistant state in rodents, but dosages used in those studies were much higher than administered in the present study (Halade et al., 2010; Bezan et al., 2018). Further studies using insulin-dependent glucose clamps might be necessary to clarify this issue, but the fact that eGP as well as plasma NEFA and hepatic triglycerides (Vogel et al., 2020) were decreased in CLA-treated cows may indicate no insulin-resistant state because of the CLA treatment. The elevated glycogen concentrations in the liver confirmed the improved glucose and energy status of CLA groups (Vogel et al., 2020), because the hepatic glycogen concentration is positively associated with the energy balance after calving (Hammon et al., 2009; Weber et al., 2013b). The CLA supplementation did not affect the hepatic glycogen concentration during the transition period in previous studies, but the energy balance was also not affected by CLA treatment in these studies (Bernal-Santos et al., 2003; Hötger et al., 2013).

The temporal pattern of gluconeogenic enzyme mRNA abundance in the liver during the transition period was consistent with previously reviewed changes and was the consequence of an increased demand for glucose and a shift in gluconeogenic substrate availability after calving (Greenfield et al., 2000; Donkin, 2016, Hammon et al., 2016). The higher abundance of $P C$ mRNA as well PCK2 mRNA observed at calving suggested an increased abundance of lactate available as a substrate for gluconeogenesis (Reynolds et al., 2003; Weber et al., 2013a; Hammon et al., 2016). Lactate originates from increased PDV release and enhanced endogenous lactate production by Cori cycling, and compensates for decreased availability of propionate because of insufficient DMI (Aschenbach et al., 2010; Weber et al., 2013a; Hammon et al., 2016). The PCK1 mRNA expression was elevated after reaching maximal DMI and was shown to be responsive to rumen propionate production, indicating the feed-forward con- 
trol of gluconeogenesis (Weber et al., 2013a; Donkin, 2016; Hammon et al., 2016). The mRNA abundance related to gluconeogenesis in the liver was less affected by CLA treatment, but decreased mRNA abundance was revealed in cows under EFA treatment during early lactation. These findings were not in accord with the elevated eGP production, increased plasma glucagon concentration and increased glucagon/insulin ratio observed in blood plasma during profiling, especially in cows treated only with EFA in early lactation, but they were associated with lower eGP production in EFA+CLA cows after calving. The reasons for these partially inconsistent findings between the observed gluconeogenic mRNA abundance in the liver and endocrine changes are presently not known. Gluconeogenic enzymes are regulated at the transcriptional level by hormones such as glucagon and insulin but are also substrate regulated (Loor, 2010; Donkin, 2016; Hammon et al., 2016). Furthermore, the decreases in mRNA abundance in the liver caused by insulin differ among the gluconeogenic enzymes during the transition period in dairy cows (Weber et al., 2017). The decreased mRNA abundance of $P C, P C K 1, P C K 2, G 6 P C$, and $P C C A$ during early lactation due to EFA treatment might be a consequence of improved insulin sensitivity. Previous studies in bulls and cows indicated enhanced insulin sensitivity when n-3 FA were supplied (Pires and Grummer, 2008; Fortin et al., 2010; HashemzadehCigari et al., 2015). The association of hepatic gluconeogenic enzyme expression with the measurement of eGP and endocrine changes showed the best correspondence under the EFA+CLA treatment. Cows treated only with EFA exhibited elevated eGP but low mRNA abundance of most of the measured enzymes on $d 28$ PP. In cows treated with CLA only, decreased eGP was associated with elevated mRNA abundance of $P C K 1$, $P C K 2, G 6 P C$, and PCCA during early lactation. The FA treatments applied in the present study clearly affected the regulation of gluconeogenic enzymes at the transcription level differentially.

\section{Somatotropic Axis and Hepatic mRNA Abundance of the GH-IGF System}

The changes in GH, IGF-I, and IGFBP-2 and IGFBP-3 in blood plasma around the time of calving and during early lactation corresponded to the changes in the energy balance in these cows (Vogel et al., 2020). The negative energy balance around the time of calving and during early lactation is associated with increasing concentrations of plasma GH and IGFBP-2 but decreasing plasma IGF-I and IGFBP-3 concentrations (Reist et al., 2003; Gross et al., 2011b; Kessler et al., 2013). In general, an insufficient energy status or undernutrition are connected with an uncoupling of the somatotropic axis, indicating increasing GH and decreasing IGF-I concentrations as well as a lower IGFBP-3 to IGFBP-2 ratio in blood plasma (Etherton and Bauman, 1998; Renaville et al., 2002; Lucy, 2004). Because the liver significantly contributes to the systemic somatotropic axis, the negative energy balance during the transition period leads to corresponding changes in key factors in the somatotropic axis in the liver. Thus, the mRNA abundance of GHR1A,IGF1, and IGFBP3 decreased, but the IGFB2 mRNA abundance increased (Kobayashi et al., 1999; Fenwick et al., 2008; Gross et al., 2011b), and the INSR mRNA abundance did not change at calving (Gross et al., 2011b; Weber et al., 2017). Similar responses regarding the abundance of these mRNA were determined in the present study, and the findings in blood plasma and the liver were consistent with the overall concept of nutrition repartitioning at the beginning of lactation (Bauman, 2000; Lucy, 2004; Gross and Bruckmaier, 2019).

Cows treated with CLA exhibit an increased plasma IGF-I concentration during early lactation (CastañedaGutiérrez et al., 2007; Csillik et al., 2017), which was also found in the present study. The improved energy status in CLA cows (Vogel et al., 2020) was closely related to the increasing IGFBP-3 to IGFBP-2 ratio in blood plasma. IGFBP-3 binds most of the IGF-I present in blood plasma, whereas IGFBP-2 may support the transport of IGF-I from blood plasma into tissue (Jones and Clemmons, 1995). The stimulation of the somatotropic axis (i.e., elevated IGF-I by decreased GH in blood plasma) takes place when plasma glucose and insulin concentrations are elevated in dairy cows during the transition period (Butler et al., 2003; Rhoads et al., 2004). Because the improved energy status in CLA cows was associated with an improved glucose and insulin status, the stimulation of the somatotropic axis in the present study was closely related to enhanced glucose and insulin availability in these cows (McGuire et al., 1995; Brameld et al., 1999; Clemmons, 2018). On the other hand, the elevated plasma IGFBP-4 concentration observed at the end of the study in CLA-treated cows might counteract the increased plasma IGF-I concentration because IGFBP-4 has mainly inhibitory effects on IGF-I action (Jones and Clemmons, 1995; Clemmons, 2018). Plasma GH was less affected by CLA treatment, even though previous findings indicated a stimulatory effect of CLA on plasma GH (Qin et al., 2018).

The CLA treatment showed only minor effects on stimulating the parameters of the somatotropic axis in the liver. The most obvious finding was the inhibition 
of IGFBP2 by CLA treatment during early lactation, which was consistent with the lower plasma IGFBP-2 concentration observed in CLA-treated cows at the end of the study. In addition, there were some minor stimulatory effects on GHR1A mRNA but not on IGF1 mRNA. Although the liver is involved in the release of components of the somatotropic axis to the blood plasma, the liver is not the only organ that contributes to the systemic somatotropic axis, and regulation of the hepatic IGF system might occur beyond the transcription level. (Thissen et al., 1994; Le Roith et al., 2001).

Changes in plasma concentrations related to the somatotropic axis were less affected by EFA treatment. These findings corresponded well with the lack of an effect of EFA treatment on the energy balance of these cows during the transition period (Vogel et al., 2020). Therefore, our results differ from earlier studies reporting a stimulatory effect of n-3 FA treatment on the somatotropic axis in cows (Carriquiry et al., 2009a; Dirandeh et al., 2016; Doyle et al., 2019). In the liver, there was also no stimulatory effect of EFA treatment on mRNA abundance related to the somatotropic axis, which again contrasted with the findings of Dirandeh et al. (2016). Interestingly, n-3 FA supplementation did not affect the stimulation of the hepatic somatotropic axis by GH treatment (Carriquiry et al., 2009b). In contrast, some inhibitory effects of EFA treatment on the mRNA abundance of IGFBPQ 2 IGFBP 3 , and INSR have been observed, but a direct inhibitory effect of $n-3$ FA on gene expression related to the somatotropic axis in the liver of cows has yet to be demonstrated.

\section{CONCLUSIONS}

Our results indicated an improved glucose and insulin status along with the stimulation of the somatotropic axis in dairy cows treated with CLA, which corresponded well with the improved energy balance during late and early lactation in CLA cows (Vogel et al., 2020). In contrast, EFA treatment had hardly any influence on the endocrine regulation of nutrient partitioning during the investigated experimental period, but resulted in highest eGP PP in cows treated exclusively with EFA and, on the contrary, showed decreased hepatic mRNA abundance of genes related to gluconeogenesis. The combined EFA+CLA treatment showed very similar results to the CLA treatment concerning the blood data related to the insulin response and the somatotropic axis, but the effects on gene expression in the liver regarding gluconeogenesis were more consistent to the effects of the EFA treatment only. No additive stimulation of the somatotropic axis by the combined EFA and CLA treatment was found in the present study.

\section{ACKNOWLEDGMENTS}

The authors express their gratitude to the staff of the Experimental Animal Facility Cattle and the "Tiertechnikum" of the Leibniz Institute for Farm Animal Biology (FBN) for their contribution to the present study and animal care. We especially thank C. Reiko, H. Pröhl, C. Fiedler, K. Kàrpàti, U. Lüdtke, P. Müntzel and U. Wiedemuth for their excellent laboratory work. We further acknowledge the quantification of IGFBP performed by Christine Höflich (Ligandis UG, Gülzow, Germany) and the help of the Cattle Breeding Organization of Mecklenburg-West Pomerania (Rinderallianz, Woldegk, Germany) in providing the assortment of cows. The present study was supported by BASF SE (Ludwigshafen, Germany) and the Federal Ministry of Food and Agriculture (BMEL, Bonn, Germany) through the Federal Office for Agriculture and Food (BLE), grant number 313-06.01-28-1-79.003-15. The publication of this article was funded by the Open Access Fund of the Leibniz Institute for Farm Animal Biology (FBN). The authors declare no conflicts of interest.

\section{REFERENCES}

Aschenbach, J. R., N. B. Kristensen, S. S. Donkin, H. M. Hammon, and G. B. Penner. 2010. Gluconeogenesis in dairy cows: The secret of making sweet milk from sour dough. IUBMB Life 62:869-877. https://doi.org/10.1002/iub.400.

Barkema, H. W., M. A. von Keyserlingk, J. P. Kastelic, T. J. G. M. Lam, C. Luby, J. P. Roy, S. J. LeBlanc, G. P. Keefe, and D. F. Kelton. 2015. Invited review: Changes in the dairy industry affecting dairy cattle health and welfare. J. Dairy Sci. 98:7426-7445. https: //doi.org/10.3168/jds.2015-9377.

Bauman, D. E. 2000. Regulation of nutrient partitioning during lactation: Homeostasis and homeorhesis revisited. Pages 311-327 in Ruminant Physiology: Digestion, Metabolism, Growth, and Reproduction. P. B. Cronje, ed. CABI Publishing, New York, NY.

Baumgard, L. H., B. A. Corl, D. A. Dwyer, A. Sæbø, and D. E. Bauman. 2000. Identification of the conjugated linoleic acid isomer that inhibits milk fat synthesis. Am. J. Physiol. Regul. Integr. Comp. Physiol. 278:R179-R184. https://doi.org/10.1152/ajpregu .2000.278.1.R179.

Bernal-Santos, G., J. W. Perfield II, D. M. Barbano, D. E. Bauman, and T. R. Overton. 2003. Production responses of dairy cows to dietary supplementation with conjugated linoleic acid (CLA) during the transition period and early lactation. J. Dairy Sci. 86:32183228. https://doi.org/10.3168/jds.S0022-0302(03)73925-3.

Bezan, P. N.. H. Holland, G. S. de Castro, J. F. R. Cardoso, P. P. Ovidio, P. C. Calder, and A. A. Jordao. 2018. High dose of a conjugated linoleic acid mixture increases insulin resistance in rats fed either a low fat or a high fat diet. Exp. Clin. Endocrinol. Diabetes. 126:379-386. https://doi.org/10.1055/s-0043-118348.

Brameld, J. M., R. S. Gilmour, and P. J. Buttery. 1999. Glucose and amino acids interact with hormones to control expression of insulin-like growth factor-I and growth hormone receptor mRNA in cultured pig hepatocytes. J. Nutr. 129:1298-1306. https://doi.org/ 10.1093/jn/129.7.1298.

Brockman, R. P., and B. Laarveld. 1986. Hormonal-regulation of metabolism in ruminants - A review. Livest. Prod. Sci. 14:313-334. https://doi.org/10.1016/0301-6226(86)90012-6.

Butler, S. T., A. L. Marr, S. H. Pelton, R. P. Radcliff, M. C. Lucy, and W. R. Butler. 2003. Insulin restores GH responsiveness dur- 
ing lactation-induced negative energy balance in dairy cattle: Effects on expression of IGF-I and GH receptor 1A. J. Endocrinol. 176:205-217. https://doi.org/10.1677/joe.0.1760205.

Carriquiry, M., W. J. Weber, C. R. Dahlen, G. C. Lamb, L. H. Baumgard, and B. A. Crooker. 2009a. Production response of multiparous Holstein cows treated with bovine somatotropin and fed diets enriched with n-3 or n-6 fatty acids. J. Dairy Sci. 92:4852-4864. https://doi.org/10.3168/jds.2008-1673.

Carriquiry, M., W. J. Weber, S. C. Fahrenkrug, and B. A. Crooker. 2009b. Hepatic gene expression in multiparous Holstein cows treated with bovine somatotropin and fed n-3 fatty acids in early lactation. J. Dairy Sci. 92:4889-4900. https://doi.org/10.3168/jds .2008-1676.

Castañeda-Gutiérrez, E., B. C. Benefield, M. J. de Veth, N. R. Santos, R. O. Gilbert, W. R. Butler, and D. E. Bauman. 2007. Evaluation of the mechanism of action of conjugated linoleic acid isomers on reproduction in dairy cows. J. Dairy Sci. 90:4253-4264. https://doi .org/10.3168/jds.2007-0117.

Chilliard, Y., A. Ferlay, and M. Doreau. 2001. Effect of different types of forages, animal fat or marine oils in cow's diet on milk fat secretion and composition, especially conjugated linoleic acid (CLA) and polyunsaturated fatty acids. Livest. Prod. Sci. 70:31-48. https: //doi.org/10.1016/S0301-6226(01)00196-8.

Clarke, S. D. 2001. Polyunsaturated fatty acid regulation of gene transcription: A molecular mechanism to improve the metabolic syndrome. J. Nutr. 131:1129-1132. https://doi.org/10.1093/jn/131.4 .1129 .

Clemmons, D. R. 2018. Role of IGF-binding proteins in regulating IGF responses to changes in metabolism. J. Mol. Endocrinol. 61:T139 T169. https://doi.org/10.1530/JME-18-0016.

Csillik, Z., V. Faigl, M. Keresztes, E. Galamb, H. M. Hammon, A Tröscher, H. Fébel, M. Kulcsár, F. Husvéth, G. Huszenicza, and W. R. Butler. 2017. Effect of pre- and postpartum supplementation with lipid-encapsulated conjugated linoleic acid on reproductive performance and the growth hormone-insulin-like growth factor-I axis in multiparous high-producing dairy cows. J. Dairy Sci. 100:5888-5898. https://doi.org/10.3168/jds.2016-12124.

Dayrit, F. M. 2015. The properties of lauric acid and their significance in coconut oil. J. Am. Oil Chem. Soc. 92:1-15. https://doi.org/10 $.1007 / \mathrm{s} 11746-014-2562-7$.

De Koster, J. D., and G. Opsomer. 2013. Insulin resistance in dairy cows. Vet. Clin. North Am. Food Anim. Pract. 29:299-322. https: //doi.org/10.1016/j.cvfa.2013.04.002.

Dirandeh, E., A. Towhidi, Z. Ansari, S. Zeinoaldini, and M. Ganjkhanlou. 2016. Effects of dietary supplementation with different polyunsaturated fatty acids on expression of genes related to somatotropic axis function in the liver, selected blood indicators, milk yield and milk fatty acids profile in dairy cows. Ann. Anim. Sci. 16:1045-1058. https://doi.org/10.1515/aoas-2016-0019.

DLG (Deutsche Landwirtschafts-Gesellschaft, German Agricultural Society). 2013. Leitfaden zur Berechnung des Energiegehaltes bei Einzel-und Mischfuttermitteln für die Schweine-und Rinderfütterung (Guidelines for calculation of energy content of single and mixed feedstuff for pigs and cattle). Stellungnahme des DLG-Arbeitskreises Futter und Fütterung.

do Prado, R. M., M. F. Palin, I. N. do Prado, G. T. Dos Santos, C. Benchaar, and H. V. Petit. 2016. Milk yield, milk composition, and hepatic lipid metabolism in transition dairy cows fed flaxseed or linola. J. Dairy Sci. 99:8831-8846. https://doi.org/10.3168/jds .2016-11003.

Donkin, S. S. 2016. Control of hepatic gluconeogenesis during the transition period. Pages 111-124 in Proc. 27th Annual Florida Ruminant Nutrition Symposium. Department of Animal Sciences, University of Florida, IFAS, Gainesville, FL.

Doyle, D. N., P. Lonergan, M. G. Diskin, K. M. Pierce, A. K. Kelly, C. Stanton, S. M. Waters, M. H. Parr, and D. A. Kenny. 2019. Effect of dietary n-3 polyunsaturated fatty acid supplementation and post-insemination plane of nutrition on systemic concentrations of metabolic analytes, progesterone, hepatic gene expression and embryo development and survival in beef heifers. Theriogenol- ogy 127:102-113. https://doi.org/10.1016/j.theriogenology.2018.12 .037 .

Drackley, J. K., T. R. Overton, and G. N. Douglas. 2001. Adaptations of glucose and long-chain fatty acid metabolism in liver of dairy cows during the periparturient period. J. Dairy Sci. 84(E. Suppl.):E100-E112.

Etherton, T. D., and D. E. Bauman. 1998. Biology of somatotropin in growth and lactation of domestic animals. Physiol. Rev. 78:745761. https://doi.org/10.1152/physrev.1998.78.3.745.

Fan, R., J. Kim, M. You, D. Giraud, A. M. Toney, S. H. Shin, S. Y. Kim, K. Borkowski, J. W. Newman, and S. Chung. 2020. $\alpha$-Linolenic acid-enriched butter attenuated high fat diet-induced insulin resistance and inflammation by promoting bioconversion of n-3 PUFA and subsequent oxylipin formation. J. Nutr. Biochem. 76:108285. https://doi.org/10.1016/j.jnutbio.2019.108285.

Fenwick, M. A., R. Fitzpatrick, D. A. Kenny, M. G. Diskin, J. Patton, J. J. Murphy, and D. C. Wathes. 2008. Interrelationships between negative energy balance (NEB) and IGF regulation in liver of lactating dairy cows. Domest. Anim. Endocrinol. 34:31-44. https:// doi.org/10.1016/j.domaniend.2006.10.002.

Fortin, M., P. Julien, Y. Couture, P. Dubreuil, P. Y. Chouinard, C. Latulippe, T. A. Davis, and M. C. Thivierge. 2010. Regulation of glucose and protein metabolism in growing steers by long-chain n-3 fatty acids in muscle membrane phospholipids is dose-dependent. Animal 4:89-101. https://doi.org/10.1017/S1751731109991042.

Gesellschaft fur Ernährungsphysiologie (German Society of Nutrition Physiology). 2001. Empfehlungen zur Energie- und Nahrstoffversorgung der Milchkuhe und Aufzuchtrinder (Recommended energy and nutrient supply of dairy cows and growing cattle). Vol. 8. DLG Verlag, Frankfurt a. M., Germany.

Gesellschaft fur Ernährungsphysiologie (German Society of Nutrition Physiology). 2008. New equations for predicting metabolisable energy of grass and maize products for ruminants. Communications of the Committee for Requirement Standards of the Society of Nutrition Physiology. Proc. Soc. Nutr. Physiol. 17:191-198.

Gesellschaft fur Ernährungsphysiologie (German Society of Nutrition Physiology). 2009. New equations for predicting metabolisable energy of compound feeds for cattle. Communications of the Committee for Requirement Standards of the Society of Nutrition Physiology. Proc. Soc. Nutr. Physiol. 18:143-146.

Greenfield, R. B., M. J. Cecava, and S. S. Donkin. 2000. Changes in mRNA expression for gluconeogenic enzymes in liver of dairy cattle during the transition to lactation. J. Dairy Sci. 83:1228-1236. https://doi.org/10.3168/jds.S0022-0302(00)74989-7.

Gross, J., H. A. van Dorland, R. M. Bruckmaier, and F. J. Schwarz. 2011a. Performance and metabolic profile of dairy cows during a lactational and deliberately induced negative energy balance with subsequent realimentation. J. Dairy Sci. 94:1820-1830. https://doi .org/10.3168/jds.2010-3707.

Gross, J., H. A. van Dorland, F. J. Schwarz, and R. M. Bruckmaier. 2011b. Endocrine changes and liver mRNA abundance of somatotropic axis and insulin system constituents during negative energy balance at different stages of lactation in dairy cows. J. Dairy Sci. 94:3484-3494. https://doi.org/10.3168/jds.2011-4251.

Gross, J. J., and R. M. Bruckmaier. 2019. Invited review: Metabolic challenges and adaptation during different functional stages of the mammary gland in dairy cows: Perspectives for sustainable milk production. J. Dairy Sci. 102:2828-2843. https://doi.org/10.3168/ jds.2018-15713.

Grossen-Rösti, L., E. C. Kessler, A. Tröscher, R. M. Bruckmaier, and J. J. Gross. 2018. Hyperglycaemia in transition dairy cows: Effects of lactational stage and conjugated linoleic acid supplementation on glucose metabolism and turnover. J. Anim. Physiol. Anim. Nutr. (Berl.) 102:483-494. https://doi.org/10.1111/jpn.12771.

Grummer, R. R., and D. J. Carroll. 1991. Effects of dietary fat on metabolic disorders and reproductive performance of dairy cattle. J. Anim. Sci. 69:3838-3852. https://doi.org/10.2527/1991.6993838x.

Halade, G. V., M. M. Rahman, and G. Fernandes. 2010. Differential effects of conjugated linoleic acid isomers in insulin-resistant fe- 
male C57Bl/6J mice. J. Nutr. Biochem. 21:332-337. https://doi .org/10.1016/j.jnutbio.2009.01.006.

Hammon, H. M., C. C. Metges, P. Junghans, F. Becker, O. Bellmann, F. Schneider, G. Nürnberg, P. Dubreuil, and H. Lapierre. 2008. Metabolic changes and net portal flux in dairy cows fed a ration containing rumen-protected fat as compared to a control diet. J. Dairy Sci. 91:208-217. https://doi.org/10.3168/jds.2007-0517.

Hammon, H. M., C. T. Schäff, J. Gruse, and C. Weber. 2016. Hepatic metabolism of glucose in the adaptation to the transition period in the dairy cow. Pages 41-52 in Proc. 5th EAAP International Symposium on Energy and Protein Metabolism and Nutrition, Krakow, Poland. Wageningen Academic Publishers, Wageningen, the Netherlands.

Hammon, H. M., G. Stürmer, F. Schneider, A. Tuchscherer, H. Blum, T. Engelhard, A. Genzel, R. Staufenbiel, and W. Kanitz. 2009. Performance and metabolic and endocrine changes with emphasis on glucose metabolism in high-yielding dairy cows with high and low fat content in liver after calving. J. Dairy Sci. 92:1554-1566. https://doi.org/10.3168/jds.2008-1634.

Hashemzadeh-Cigari, F., G. R. Ghorbani, M. Khorvash, A. Riasi, A. Taghizadeh, and Q. Zebeli. 2015. Supplementation of herbal plants differently modulated metabolic profile, insulin sensitivity, and oxidative stress in transition dairy cows fed various extruded oil seeds. Prev. Vet. Med. 118:45-55. https://doi.org/10.1016/j .prevetmed.2014.10.013.

Haubold, S., C. Kröger-Koch, A. Starke, A. Tuchscherer, A. Tröscher, H. Kienberger, M. Rychlik, U. Bernabucci, E. Trevisi, and H. M. Hammon. 2020. Effects of abomasal infusion of essential fatty acids and conjugated linoleic acid on performance and fatty acid, antioxidative, and inflammatory status in dairy cows. J. Dairy Sci. 103:972-991. https://doi.org/10.3168/jds.2019-17135.

Hötger, K., H. M. Hammon, C. Weber, S. Görs, A. Tröscher, R. M. Bruckmaier, and C. C. Metges. 2013. Supplementation of conjugated linoleic acid in dairy cows reduces endogenous glucose production during early lactation. J. Dairy Sci. 96:2258-2270. https:/ /doi.org/10.3168/jds.2012-6127.

Jones, J. I., and D. R. Clemmons. 1995. Insulin-like growth factors and their binding proteins: Biological actions. Endocr. Rev. 16:3-34. https://doi.org/10.1210/edrv-16-1-3.

Kessler, E. C., J. J. Gross, and R. M. Bruckmaier. 2013. Different adaptation of IGF-I and its IGFBPs in dairy cows during a negative energy balance in early lactation and a negative energy balance induced by feed restriction in mid-lactation. Vet. Med. Czech. 58:459-467.

Kobayashi, Y., C. K. Boyd, C. J. Bracken, W. R. Lamberson, D. H Keisler, and M. C. Lucy. 1999. Reduced growth hormone receptor (GHR) messenger RNA in liver of periparturient cattle is caused by a specific down-regulation of GHR 1A that is associated with decreased insulin-like growth factor-I. Endocrinology 140:39473954. https://doi.org/10.1210/endo.140.9.7000.

Kusenda, M., M. Kaske, M. Piechotta, L. Locher, A. Starke, K. Huber, and J. Rehage. 2013. Effects of dexamethasone-21-isonicotinate on peripheral insulin action in dairy cows 5 days after surgical correction of abomasal displacement. J. Vet. Intern. Med. 27:200-206. https://doi.org/10.1111/jvim.12010.

Le Roith, D., C. Bondy, S. Yakar, J. L. Liu, and A. Butler. 2001. The somatomedin hypothesis: 2001. Endocr. Rev. 22:53-74. https://doi .org/10.1210/edrv.22.1.0419.

Linzell, J. L. 1972. Mechanism of secretion of the aqueous phase of milk. J. Dairy Sci. 55:1316-1322. https://doi.org/10.3168/jds .S0022-0302(72)85670-4.

Loor, J. J. 2010. Genomics of metabolic adaptations in the peripartal cow. Animal 4:1110-1139. https://doi.org/10.1017/ S1751731110000960.

Lucy, M. C. 2004. Mechanisms linking the somatotropic axis with insulin: Lessons from the postpartum dairy cow. Proc. N.Z. Soc. Anim. Prod. 64:19-23.

Mach, N., R. L. G. Zom, H. C. A. Widjaja, P. G. van Wikselaar, R. E. Weurding, R. M. A. Goselink, J. van Baal, M. A. Smits, and A. M. van Vuuren. 2013. Dietary effects of linseed on fatty acid composition of milk and on liver, adipose and mammary gland metabolism of periparturient dairy cows. J. Anim. Physiol. Anim. Nutr. (Berl.) 97(Suppl 1):89-104. https://doi.org/10.1111/jpn.12042.

Mashek, D. G., and R. R. Grummer. 2003. Effects of long chain fatty acids on lipid and glucose metabolism in monolayer cultures of bovine hepatocytes. J. Dairy Sci. 86:2390-2396. https://doi.org/ 10.3168/jds.S0022-0302(03)73833-8.

McGuire, M. A., D. A. Dwyer, R. J. Harrell, and D. E. Bauman. 1995. Insulin regulates circulating insulin-like growth-factors and some of their binding-proteins in lactating cows. Am J Physiol. 269:E723E730. https://doi.org/10.1152/ajpendo.1995.269.4.E723.

Odens, L. J., R. Burgos, M. Innocenti, M. J. VanBaale, and L. H. Baumgard. 2007. Effects of varying doses of supplemental conjugated linoleic acid on production and energetic variables during the transition period. J. Dairy Sci. 90:293-305. https://doi.org/10 .3168/jds.S0022-0302(07)72630-9.

Pires, J. A. A., and R. R. Grummer. 2008. Specific fatty acids as metabolic modulators in the dairy cow. Rev. Bras. Zootec. 37:287-298. https://doi.org/10.1590/S1516-35982008001300033.

Qin, N., A. R. Bayat, E. Trevisi, A. Minuti, P. Kairenius, S. Viitala, M. Mutikainen, H. Leskinen, K. Elo, T. Kokkonen, and J. Vilkki. 2018. Dietary supplement of conjugated linoleic acids or polyunsaturated fatty acids suppressed the mobilization of body fat reserves in dairy cows at early lactation through different pathways. J. Dairy Sci. 101:7954-7970. https://doi.org/10.3168/jds .2017-14298.

Reist, M., D. Erdin, D. von Euw, K. Tschuemperlin, H. Leuenberger, C. Delavaud, Y. Chilliard, H. M. Hammon, N. Kuenzi, and J. W. Blum. 2003. Concentrate feeding strategy in lactating dairy cows: Metabolic and endocrine changes with emphasis on leptin. J. Dairy Sci. 86:1690-1706. https://doi.org/10.3168/jds.S0022 $-0302(03) 73755-2$.

Renaville, R., M. Hammadi, and D. Portetelle. 2002. Role of the somatotropic axis in the mammalian metabolism. Domest. Anim. Endocrinol. 23:351-360. https://doi.org/10.1016/S0739 -7240(02)00170-4.

Reynolds, C. K., P. C. Aikman, B. Lupoli, D. J. Humphries, and D. E. Beever. 2003. Splanchnic metabolism of dairy cows during the transition from late gestation through early lactation. J. Dairy Sci. 86:1201-1217. https://doi.org/10.3168/jds.S0022-0302(03)73704 -7 .

Rhoads, R. P., J. W. Kim, B. J. Leury, L. H. Baumgard, N. Segoale, S. J. Frank, D. E. Bauman, and Y. R. Boisclair. 2004. Insulin increases the abundance of the growth hormone receptor in liver and adipose tissue of periparturient dairy cows. J. Nutr. 134:10201027. https://doi.org/10.1093/jn/134.5.1020.

Risérus, U., P. Arner, K. Brismar, and B. Vessby. 2002. Treatment with dietary trans10cis12 conjugated linoleic add causes isomermspecific insulin resistance in obese men with the metabolic syndrome. Diabetes Care 25:1516-1521. https://doi.org/10.2337/ diacare.25.9.1516.

Ruijter, J. M., M. W. Pfaffl, S. Zhao, A. N. Spiess, G. Boggy, J. Blom, R. G. Rutledge, D. Sisti, A. Lievens, K. De Preter, S. Derveaux, J. Hellemans, and J. Vandesompele. 2013. Evaluation of qPCR curve analysis methods for reliable biomarker discovery: Bias, resolution, precision, and implications. Methods 59:32-46. https://doi.org/10 .1016/j.ymeth.2012.08.011.

Saremi, B., H. Sauerwein, S. Dänicke, and M. Mielenz. 2012. Technical note: Identification of reference genes for gene expression studies in different bovine tissues focusing on different fat depots. J. Dairy Sci. 95:3131-3138. https://doi.org/10.3168/jds.2011-4803.

Saremi, B., S. Winand, P. Friedrichs, A. Kinoshita, J. Rehage, S. Danicke, S. Haussler, G. Breves, M. Mielenz, and H. Sauerwein. 2014. Longitudinal profiling of the tissue-specific expression of genes related with insulin sensitivity in dairy cows during lactation focusing on different fat depots. PLoS One 9:e86211. https:// doi.org/10.1371/journal.pone.0086211.

Sato, H. 1994. Plasma ketone levels in neonatal calves fed mediumchain triglycerides in milk. J. Vet. Med. Sci. 56:781-782. https:// doi.org/10.1292/jvms.56.781.

Scheuer, B. H., Y. Zbinden, P. Schneiter, L. Tappy, J. W. Blum, and H. M. Hammon. 2006. Effects of colostrum feeding and glucocor- 
ticoid administration on insulin-dependent glucose metabolism in neonatal calves. Domest. Anim. Endocrinol. 31:227-245. https:// doi.org/10.1016/j.domaniend.2005.11.004.

Steinhoff-Wagner, J., S. Gors, P. Junghans, R. M. Bruckmaier, E. Kanitz, C. C. Metges, and H. M. Hammon. 2011. Intestinal glucose absorption but not endogenous glucose production differs between colostrum- and formula-fed neonatal calves. J. Nutr. 141:48-55. https://doi.org/10.3945/jn.110.128652.

Thissen, J. P., J. M. Ketelslegers, and L. E. Underwood. 1994. Nutritional regulation of the insulin-like growth factors. Endocr. Rev. 15:80-101. https://doi.org/10.1210/edrv-15-1-80.

Urrutia, N., and K. J. Harvatine. 2017. Effect of conjugated linoleic acid and acetate on milk fat synthesis and adipose lipogenesis in lactating dairy cows. J. Dairy Sci. 100:5792-5804. https://doi.org/ 10.3168 /jds.2016-12369.

Vicari, T., J. J. G. C. van den Borne, W. J. J. Gerrits, Y. Zbinden, and J. W. Blum. 2008. Postprandial blood hormone and metabolite concentrations influenced by feeding frequency and feeding level in veal calves. Domest. Anim. Endocrinol. 34:74-88. https://doi.org/ 10.1016/j.domaniend.2006.11.002.

Vogel, L., M. Gnott, C. Kröger-Koch, D. Dannenberger, A. Tuchscherer, A. Tröscher, H. Kienberger, M. Rychlik, A. Starke, L. Bachmann, and H. M. Hammon. 2020. Effects of abomasal infusion of essential fatty acids together with conjugated linoleic acid in late and early lactation on performance, milk and body composition, and plasma metabolites in dairy cows. J. Dairy Sci. 103:7431-7450. https://doi.org/10.3168/jds.2019-18065.

von Soosten, D., U. Meyer, M. Piechotta, G. Flachowsky, and S. Danicke. 2012. Effect of conjugated linoleic acid supplementation on body composition, body fat mobilization, protein accretion, and energy utilization in early lactation dairy cows. J. Dairy Sci. 95:1222-1239. https://doi.org/10.3168/jds.2011-4548.

Weber, C., C. Hametner, A. Tuchscherer, B. Losand, E. Kanitz, W. Otten, H. Sauerwein, R. M. Bruckmaier, F. Becker, W. Kanitz, and H. M. Hammon. 2013a. Hepatic gene expression involved in glucose and lipid metabolism in transition cows: Effects of fat mobilization during early lactation in relation to milk performance and metabolic changes. J. Dairy Sci. 96:5670-5681. https://doi .org/10.3168/jds.2012-6277.

Weber, C., C. Hametner, A. Tuchscherer, B. Losand, E. Kanitz, W. Otten, S. P. Singh, R. M. Bruckmaier, F. Becker, W. Kanitz, and H. M. Hammon. 2013b. Variation in fat mobilization during early lactation differently affects feed intake, body condition, and lipid and glucose metabolism in high-yielding dairy cows. J. Dairy Sci. 96:165-180. https://doi.org/10.3168/jds.2012-5574.

Weber, C., C. T. Schäff, U. Kautzsch, S. Börner, S. Erdmann, R. M. Bruckmaier, M. Röntgen, B. Kuhla, and H. M. Hammon. 2017. Variable liver fat concentration as a proxy for body fat mobilization postpartum has minor effects on insulin-induced changes in hepatic gene expression related to energy metabolism in dairy cows. J. Dairy Sci. 100:1507-1520. https://doi.org/10.3168/jds .2016-11808.

Weber, C., C. T. Schäff, U. Kautzsch, S. Börner, S. Erdmann, S. Görs, M. Röntgen, H. Sauerwein, R. M. Bruckmaier, C. C. Metges, B. Kuhla, and H. M. Hammon. 2016. Insulin-dependent glucose metabolism in dairy cows with variable fat mobilization around calving. J. Dairy Sci. 99:6665-6679. https://doi.org/10.3168/jds .2016-11022.

White, H. M., S. L. Koser, and S. S. Donkin. 2011. Characterization of bovine pyruvate carboxylase promoter 1 responsiveness to serum from control and feed-restricted cows. J. Anim. Sci. 89:1763-1768. https://doi.org/10.2527/jas.2010-3407.

Wirthgen, E., C. Höflich, M. Spitschak, C. Helmer, B. Brand, J. Langbein, F. Metzger, and A. Hoeflich. 2016. Quantitative Western ligand blotting reveals common patterns and differential features of IGFBP-fingerprints in domestic ruminant breeds and species. Growth Horm. IGF Res. 26:42-49. https://doi.org/10.1016/j.ghir .2015.11.001.

Zachut, M., A. Arieli, H. Lehrer, L. Livshitz, S. Yakoby, and U. Moallem. 2010. Effects of increased supplementation of n-3 fatty acids to transition dairy cows on performance and fatty acid profile in plasma, adipose tissue, and milk fat. J. Dairy Sci. 93:5877-5889. https://doi.org/10.3168/jds.2010-3427.

\section{ORCIDS}

A. Hoeflich @ https://orcid.org/0000-0003-2018-2836

A. Tröscher (ㄴ) https://orcid.org/0000-0002-4198-4427

J. J. Gross ๑ https://orcid.org/0000-0002-2578-6076

R. M. Bruckmaier @ https://orcid.org/0000-0002-9374-5890

L. Bachmann () https://orcid.org/0000-0003-0681-4999

H. M. Hammon @ https://orcid.org/0000-0001-8698-1257 